\title{
19. MIOCENE TO HOLOCENE DIATOM BIOSTRATIGRAPHY FROM BAFFIN BAY AND LABRADOR SEA, OCEAN DRILLING PROGRAM SITES 645 AND 646 ${ }^{1}$
}

\author{
Anne-Lise Monjanel ${ }^{2}$ and Jack G. Baldauf ${ }^{3}$
}

\begin{abstract}
Diatoms occur sporadically in lower Miocene to Holocene sediments recovered at ODP Site 645 and in upper Pliocene to Holocene sediments at ODP Site 646. The diatom assemblage at Site 645 contains rare stratigraphic indicators. Fragmentation of frustules and the occurrence of species characteristic of high-latitude shelf, upper-slope environments suggest current transportation from the shelf. The diatom abundance and preservation at Site 646 probably reflect climatic changes and are also affected by dissolution, but it is not possible to detect the dominant factor. Therefore, the stratigraphic ranges of the primary and secondary biostratigraphic indicators are often unreliable.
\end{abstract}

\section{INTRODUCTION}

Leg 105 is the first Deep Sea Drilling Project-Ocean Drilling Program (DSDP-ODP) cruise to drill in Baffin Bay and to core Neogene sediments in the Labrador Sea continuously (Sites 645 and 646, Fig. 1). Some of the objectives of Leg 105 included the recovery of continuous stratigraphic sequences in the Labrador Sea and Baffin Bay, the completion of a high-resolution stratigraphy, and the correlation of this stratigraphy with those previously completed for the North Atlantic and the NorwegianGreenland Sea. Investigating the responses of oceanographic circulation to changing climatic conditions was another interest of the Leg 105 Shipboard Scientific Party.

Diatom biostratigraphic and paleoceanographic studies have previously been conducted for Neogene and Quaternary sediments from the high-latitude Atlantic (north of $50^{\circ} \mathrm{N}$; Baldauf, 1984, 1987; Schrader, 1979) and from the Norwegian-Greenland Sea (Schrader and Fenner, 1976; Dzinoridze et al., 1978; Thiede et al., in press).

We recovered Pliocene and Pleistocene diatoms at Sites 645 and 646. At Site 645, diatoms occur sporadically within Pliocene and Pleistocene sediments. The diatom assemblage is composed of species typical of shelf and upper-slope deposits, suggesting downslope redeposition of the sediments. The diatom flora at Site 646 consists of three primary components: (1) a high-latitude assemblage composed of nearshore species similar to those observed at Site 645, in the Norwegian-Greenland Sea (Schrader and Fenner, 1976), in the Bering Sea (Baldauf, 1982; Sancetta, 1982), and elsewhere in Baffin Bay (Williams, 1986); (2) an assemblage similar to that defined for the warmtemperate North Atlantic (Schrader, 1979; Baldauf, 1984, 1986, 1987); and (3) an assemblage composed of pelagic species common to the Norwegian-Greenland Sea (Schrader and Fenner, 1976, Dzinoridze et al., 1979), the North Pacific (Barron, 1980, 1985a; Koizumi, 1973, Koizumi and Tanimura, 1985; Akiba, 1985), and the Bering Sea (Sancetta, 1982). The occurrence of these three distinct diatom assemblages within the sediments recovered at Site 646 reflects changes in surface-water conditions.

Primary biostratigraphic markers do occur at Site 646, but their stratigraphic range is generally unreliable because of the in-

\footnotetext{
${ }^{1}$ Srivastava, S. P., Arthur, M., Clement, B., et al., 1989. Proc. ODP, Sci. Results, 105: College Station, TX (Ocean Drilling Program).

2 Université de Bretagne Occidentale, GIS "Océanologie et Géodynamique," 6, avenue Victor Le Gorgeu, 29287 Brest Cedex, France.

${ }^{3}$ Ocean Drilling Program, Texas A\&M University Research Park, 1000 Discovery Drive, College Station, TX 77840.
}

consistent occurrence and poor to moderate preservation. Therefore, the diatom biostratigraphy at Site 646 relies in part on secondary stratigraphic markers.

\section{METHODS}

Approximately $1.5 \mathrm{~cm}^{3}$ of the sample was placed into a $400 \mathrm{~mL}$ beaker and disaggregated by the addition of $10 \mathrm{~mL}$ of $30 \%$ hydrogen peroxide. We then added $30 \mathrm{~mL}$ of $37 \% \mathrm{HCl}$ and gently heated the sample until carbonates and organic carbons were removed. We diluted the sample by adding approximately $300 \mathrm{~mL}$ distilled water and decanted it after $2 \mathrm{hr}$ settling time. We repeated the decanting process until a $\mathrm{pH}$ of 6 was reached. Strewn slides were prepared on $22 \times 30 \mathrm{~mm}$ cover glasses and mounted in Hyrax on $22 \times 75 \mathrm{~mm}$ glass slides.

For Site 646 material, we reexamined strewn slides of acid-clean material prepared aboard JOIDES Resolution as well as additional samples processed at onshore facilities. For material from Holes $645 \mathrm{~B}$ to $645 \mathrm{~F}$, most of the samples we studied consisted of core-catcher samples observed on board JOIDES Resolution and reexamined onshore. Table 1 lists the abundance and preservation of samples that contain diatoms from Site 645 . We examined one strewn slide of each sample in its entirety at $\times 500$ with a light microscope; we confirmed species identifications at $\times 1250$. The range chart for Site 646 is presented in Table 2 . Species were recorded as abundant $(\mathrm{A})$ if two or more specimens were present in one field of view at $\times 500$, common $(C)$ if one specimen occurred in two fields of view, few (F) if one specimen was observed in each horizontal transect, and rare $(R)$ if specimens were encountered less frequently than that.

The quality of fossil preservation in the samples-poor $(\mathrm{P})$, moderate $(\mathrm{M})$, and good $(\mathrm{G})$ - is based on the number of finely silicified species such as Pseudoeunotia doliolus and the Nitzschia group, compared with the number of heavily silicified ones such as Stephanopyxis horridus, Thalassiosira zabelinae, and Coscinodiscus marginatus. The geochronology used in this report follows that of Berggren et al. (1985). Correlation of the diatom events to the magnetostratigraphic record follows that of Barron (1985b), Barron et al. (1985), Baldauf (1984, 1987), Morley et al. (1982), Koizumi and Tanirama (1985), and Sancetta and Silvestri $(1984,1986)$ (Fig. 2).

\section{RESULTS}

\section{Site 645}

Site $645\left(70^{\circ} 27.43^{\prime} \mathrm{N}, 64^{\circ} 39.26^{\prime} \mathrm{W}\right)$ is situated on the lower continental slope east of Baffin Island in water depths of about $2006 \mathrm{~m}$ (Fig. 1). The sediments recovered have a pronounced terrigenous character with surprisingly few microfossils (with the exception of dinocysts), which could be the consequence of low surface-water productivity within this region of Baffin Bay. Diatoms occur sporadically in Miocene to Holocene sediments. The diatom assemblages at this site are characterized by species typical of high-latitude shelf, upper-slope environments. 


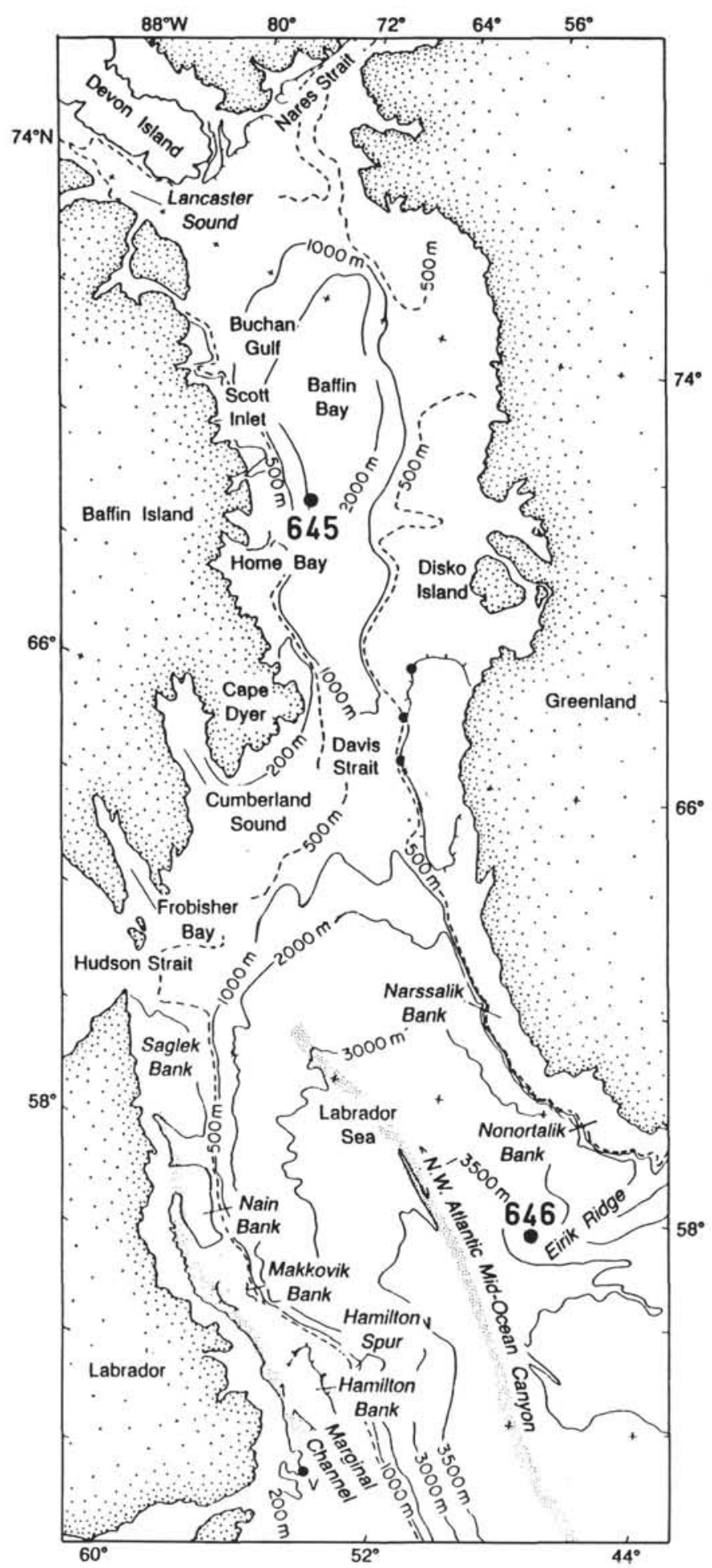

Figure 1. Geographic location of Site 645 in Bafin Bay and Site 646 in the Labrador Sea.

Seven holes (645A-645G) were drilled at Site 645 (Fig. 3). Table 1 lists those samples containing diatoms, which are indicated by an arrow in Figure 3 . We observed no diatoms in the other core-catcher samples. Diatom preservation is generally moderate, and diatoms are common to rare in these samples. Although primary biostratigraphic markers are typically absent, secondary biostratigraphic markers allow age assignment of the sediments.
Table 1. Abundance and preservation of diatoms for analyzed samples from Site 645 .

\begin{tabular}{ccc}
\hline $\begin{array}{c}\text { Core, section, } \\
\text { interval }(\mathrm{cm})\end{array}$ & Abundance & Preservation \\
\hline 105-645B-24X-3, 66-67 & $\mathrm{R}$ & $\mathrm{P}$ \\
$645 \mathrm{~B}-28 \mathrm{X}, \mathrm{CC}$ & $\mathrm{R}$ & $\mathrm{P}$ \\
$645 \mathrm{~B}-30 \mathrm{X}, \mathrm{CC}$ & $\mathrm{F}$ & $\mathrm{P}$ \\
$645 \mathrm{C}-1 \mathrm{H}-1, \mathrm{1}-5$ & $\mathrm{~F}$ & $\mathrm{G}$ \\
$645 \mathrm{D}-2 \mathrm{R}-3,70-72$ & $\mathrm{~F}$ & $\mathrm{G}$ \\
$645 \mathrm{D}-2 \mathrm{R}, \mathrm{CC}$ & $\mathrm{F}$ & $\mathrm{G}$ \\
$645 \mathrm{D}-8 \mathrm{R}-3,80-81$ & $\mathrm{R}$ & $\mathrm{P}$ \\
$645 \mathrm{D}-8 \mathrm{R}, \mathrm{CC}$ & $\mathrm{R}$ & $\mathrm{P}$ \\
$645 \mathrm{D}-10 \mathrm{R}, \mathrm{CC}$ & $\mathrm{F}$ & $\mathrm{M}$ \\
$645 \mathrm{D}-11 \mathrm{R}-3,48-50$ & $\mathrm{~F}$ & $\mathrm{G}$ \\
$645 \mathrm{E}-7 \mathrm{R}, \mathrm{CC}$ & $\mathrm{F}$ & $\mathrm{G}$ \\
$645 \mathrm{E}-8 \mathrm{R}-6,48-50$ & $\mathrm{~F}$ & $\mathrm{G}$ \\
$645 \mathrm{E}-8 \mathrm{R}, \mathrm{CC}$ & $\mathrm{A}$ & $\mathrm{G}$ \\
$645 \mathrm{E}-9 \mathrm{R}-2,37-39$ & $\mathrm{~F}$ & $\mathrm{G}$ \\
$645 \mathrm{E}-9 \mathrm{R}-4,37-39$ & $\mathrm{R}$ & $\mathrm{P}$ \\
$645 \mathrm{E}-9 \mathrm{R}-6,37-39$ & $\mathrm{~F}$ & $\mathrm{G}$ \\
$645 \mathrm{E}-9 \mathrm{R}, \mathrm{CC}$ & $\mathrm{A}$ & $\mathrm{G}$ \\
$645 \mathrm{E}-10 \mathrm{R}, \mathrm{CC}$ & $\mathrm{R}$ & $\mathrm{P}$ \\
$645 \mathrm{E}-35 \mathrm{R}, \mathrm{CC}$ & $\mathrm{F}$ & $\mathrm{P}$ \\
$645 \mathrm{E}-44 \mathrm{R}-2,37-39$ & $\mathrm{R}$ & $\mathrm{P}$ \\
$645 \mathrm{E}-50 \mathrm{R}-1,40-42$ & $\mathrm{R}$ & $\mathrm{M}$ \\
$645 \mathrm{~F}-1 \mathrm{H}-1,0-2$ & $\mathrm{~F}$ & $\mathrm{G}$ \\
\hline R & & \\
rare, F $=$ few, A = abundant. P = poor, G & & \\
g0od, M $=$ moderate. & &
\end{tabular}

\section{Biostratigraphy}

\section{Holes $645 A$ and $645 B$}

With the exception of Samples 105-645B-24X-3, 66-67 cm (220 mbsf), 105-645B-28X, CC (264 mbsf), and 105-645B-30X, CC (283.8 mbsf), diatoms are generally absent from samples examined from Holes 645A and 645B. We observed a number of rare diatoms in these samples, including Thalassionema nitzschioides, Coscinodiscus marginatus, Melosira sol, Porosira glacialis, Thalassiothrix longissima, Nitzschia cylindra, N. grunowii, and some Cocconeis, Xanthiopyxis, and Nitzschia species. Although we did not observe primary biostratigraphic indicators, the diatom assemblage is characteristic of the PliocenePleistocene. Nitzschia cylindra (referred to by Koizumi, 1973, as Fragilariopsis cylindrus) and P. glacialis were reported in Pliocene and Pleistocene sediments from Japan (Koizumi, 1973; Akiba, 1985), the North Pacific (Koizumi, 1973), and the Bering Sea (Baldauf, 1982; Sancetta, 1982). Porosira glacialis was also reported from surface sediments in Baffin Bay (Williams, 1986).

\section{Hole $645 C$}

Nitzschia grunowii and Porosira glacialis were observed in Sample 105-645C-1H-1, 3-5 cm (1.5 mbsf), suggesting a Pliocene-Pleistocene age.

\section{Hole $645 D$}

Diatoms were observed in six of the 20 samples examined from this hole: Sample 105-645D-2R-3, 70-72 cm (275.5 mbsf), 105-645D-2R, CC (282.5 mbsf), 105-645D-8R-3, 80-81 cm (349 mbsf), 105-645D-8R, CC (350 mbsf), 105-645D-10R, CC (369.4 mbsf), and 105-645D-11R-3, 48-50 cm (373.5 mbsf). The diatom assemblage suggests a Pliocene-Pleistocene age, and the following species were observed among these samples: Actinocyclus curvatulus, Actinoptychus senarius, Coscinodiscus marginatus, Melosira sol, Nitzschia cylindra, N. grunowii, Paralia sulcata, Rhizosolenia hebetata, Thalassionema nitzschioides, Thalassiosira decipiens, T. eccentrica, T. gravida, T. oestrupii, and $T$. cf. trifulta. Rare, reworked specimens of Mediaria splendida (middle to lower upper Miocene) also occur in two of these samples. 


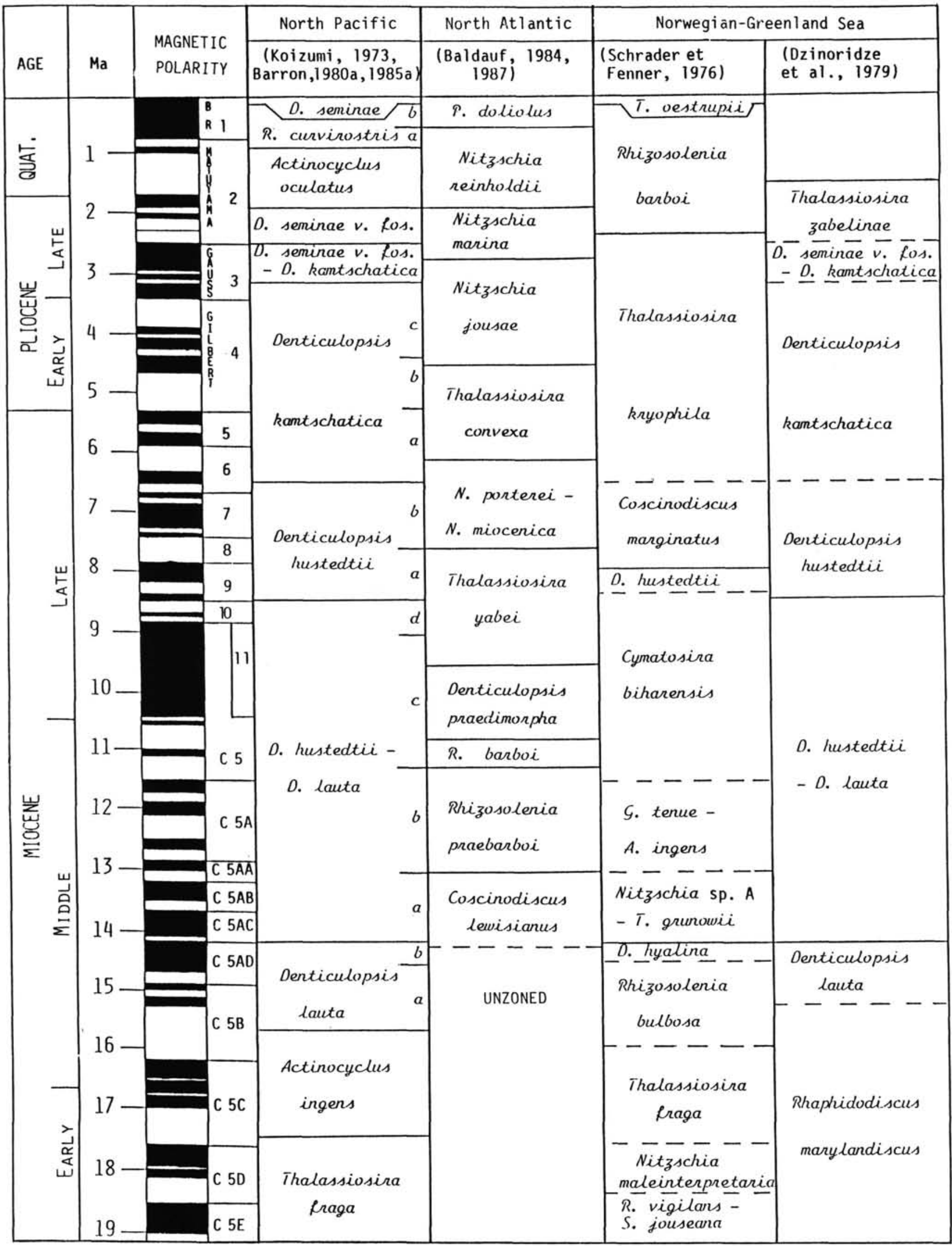

Figure 2. Correlation of high-latitude, late Neogene diatom zonations: the North Pacific (Koizumi, 1973; Barron, 1980, 1985a), the North Atlantic (Baldauf, 1984, 1987), and the Norwegian-Greenland Sea (Schrader and Fenner, 1976; and Dzinoridze et al., 1979) with the magnetostratigraphy of Berggren et al. (1985). 


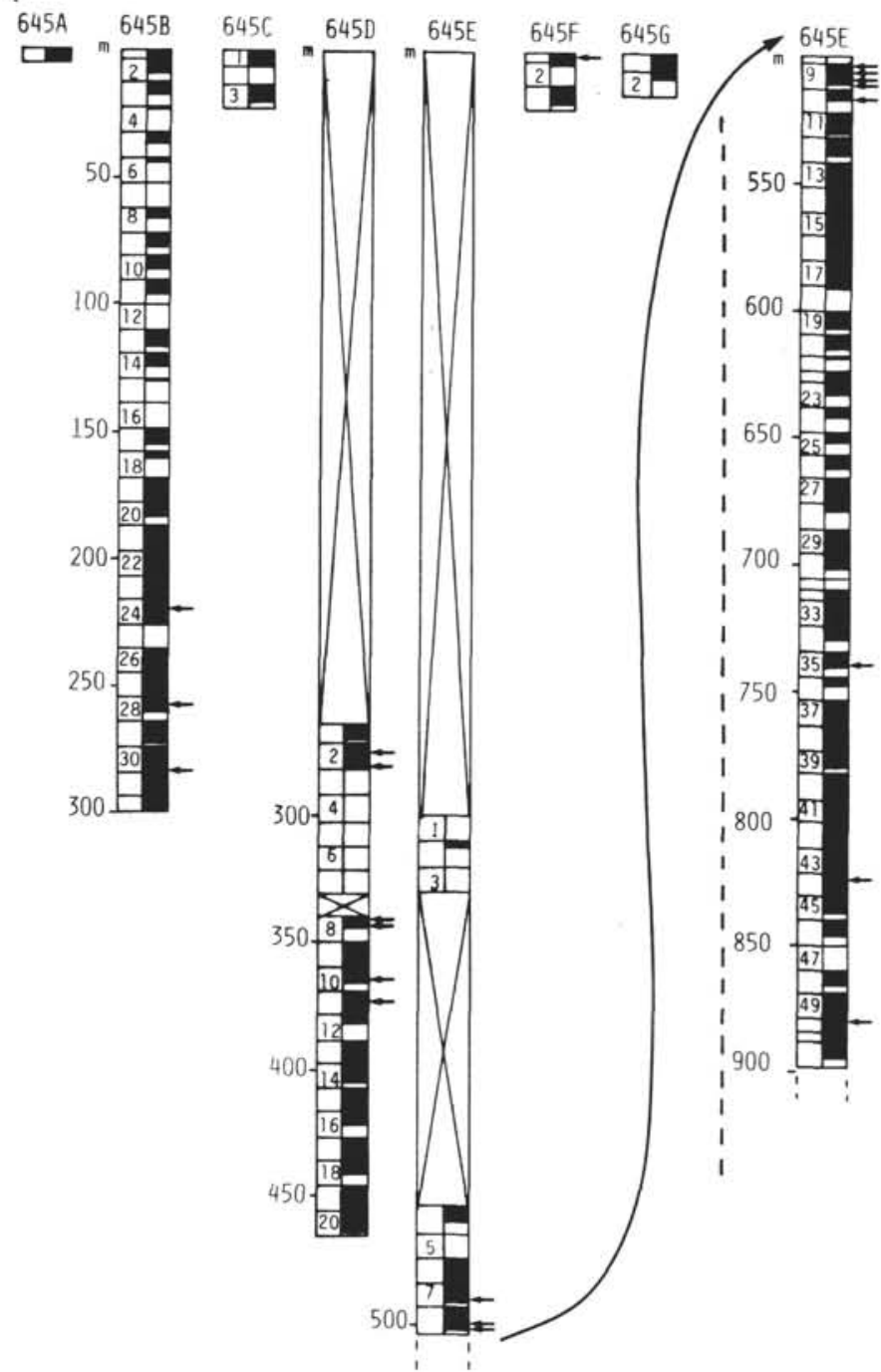

Figure 3. Stratigraphic correlation between cores from Holes 645A$645 \mathrm{G}$ (core recovery is indicated by darker intervals) with the position of the analyzed samples that contain diatoms (arrow).

\section{Hole $645 E$}

With the exception of samples from Cores 105-645E-7R to 105645E-10R (484.1-522.6 mbsf), 105-645E-35R (734-743.7 mbsf), 105-645E-44R (820.8-830.5 mbsf), and 105-645E-54R (907.2$916.8 \mathrm{mbsf}$ ), diatoms were not observed in samples examined from this hole. The following species, which suggest a PliocenePleistocene age, were observed among the samples: Actinoptychus senarius, Coscinodiscus marginatus, Nitzschia cf. cylindra, Paralia sulcata, Rhizosolenia hebetata, R. barboi, Stephanopyxis turris, Stephanogonia hanzawae, Thalassionema nitzschioides, Thalassiothrix longissima, Thalassiosira spp., belonging to the "plicate group," and some benthic species.

The rare occurrence of $S$. hanzawae in these samples is unusual as this species was thought to be restricted to middle to late Miocene in the Pacific. Therefore, this species may have an extended range occurring well into the Pliocene in the Labrador Sea and possibly in Baffin Bay (see Site 646, Table 2). It is also possible that the specimens of this species are reworked. Samples 105-645E-9R-6, 37-39 cm (512 mbsf), and 105-645E-9R, CC (513 mbsf), also contain reworked specimens of Goniothecium decoratum (Eocene to early Miocene). Occasional specimens of pyritized diatoms were recorded from samples between Core 105-645E-11R and the base of the hole (369-466 mbsf).

\section{Hole $645 F$}

Sample $105-645 \mathrm{~F}-1 \mathrm{H}-1,0-2 \mathrm{~cm}$ (1 mbsf), contains well-preserved diatoms, including Actinocylus curvatulus, Coscinodiscus oculus-iridis, Rhizosolenia hebetata, Thalassiosira trifulta, and Thalassiothrix longissima. One specimen each of both Nitzschia cylindra and $N$. grunowii was also recorded in this sample. These two species characterize the Pliocene-Pleistocene, but their rare occurrence disallows any accurate age determination.

\section{Paleoenvironment}

The diatom flora observed at Site 645 is typical of a high-latitude shelf, upper-slope environment. Using factor analysis, Williams (1986) recently described five different components among the diatom assemblages observed in surface sediments at numerous localities in Baffin Bay, two of which were recognized at Site 645 .

One of these assemblages is dominated by Actinocyclus curvatulus and Thalassiosira trifulta and is characteristic of summer pack-ice (Williams, 1986). This diatom assemblage occurs in the current gyre in north central Baffin Bay, where Site 645 is located, and was recognized in Site 645 sediments. In this area, the pack-ice usually forms in late October and lasts through July (Markham, 1981). Actinocyclus curvatulus and Thalassiosira trifulta commonly occur in Site 645 samples and were previously recorded in Pliocene and Pleistocene sediments from the high-latitude North Pacific (Koizumi, 1973) and the Bering Sea (Baldauf, 1982; Sancetta, 1982; Sancetta and Silvestri, 1984, 1986).

The other diatom assemblage recognized within Site 645 sediments is a marine littoral assemblage dominated by Thalassionema nitzschioides, Porosira glacialis, Navicula spp., Diploneis spp., and Cocconeis spp. This assemblage is characteristic of marine littoral environments and occurs on the continental shelves of Baffin Island and Greenland (Williams, 1986). At Site 645 Thalassionema nitzschioides, Porosira glacialis, and some neritic species such as Actinoptychus senarius, Actinoptychus vulgaris, Biddulphia aurita, Rhaphoneis amphiceros, Navicula sp., Diploneis spp., Grammatophora spp., and Navicula spp. were regularly observed. Most likely, many diatoms recorded at Site 645 are redeposits from the continental shelf. The occurrence of Melosira sol, N. cylindra, N. grunowii, and Thalassiosira lacustris supports this hypothesis.

Melosira sol occurs in most samples examined from Site 645. The maximum abundance of this species in Quaternary sediments of the Bering Sea was reported by Sancetta (1982) to occur in shallow water (less than 50-m water depth). The abundance of this species in the Bering Sea also decreases with increased water depths (Sancetta, 1982). Within the Bering Sea, Nitzschia cylindra and $N$. grunowii, which are commonly found in Site 645 material, are most abundant in sediments deposited on the continental shelf (Baldauf, 1982; Sancetta, 1982). Nitzschia cylindra is a bipolar species often associated with pack-ice as well as with plankton (Sancetta, 1982). Within Baffin Bay surface sediments, $N$. cylindra characterizes the influence of the West Greenland Current (Williams, 1986).

Few specimens of Thalassiosira belonging to the "plicate group" were found in Site 645 material. Sancetta (1982) described a "plicate" form referred to as Thalassiosira lacustris from Bering and Chukchi sea-shelf sediments. Hustedt (1930), Zabelina (1934), and Gran (1904) described this form as a littoral species restricted to the shelf of the northern seas, sometimes with a tolerance to low-saline environments induced by melting ice. This species was also observed in Baffin Bay surface sediments (Williams, 1986).

Most of the diatom frustules in Site 645 samples are fragmented. This fragmentation, combined with the neritic affinities of the diatom assemblage, suggests that most of the dia- 
toms occurring at Site 645 are redeposits from shallower water environments. The association of diatoms with turbiditic sediments supports this conclusion (see "Site 645" in Srivastava, Arthur, et al., 1987).

\section{Site 646}

Site $646\left(58^{\circ} 12.56^{\prime} \mathrm{N}, 48^{\circ} 22.15^{\prime} \mathrm{W}\right)$ is located in the southern Labrador Sea on the northwestern flank of Erik Ridge and off the southern tip of Greenland (Fig. 1). Table 2 and Figure 4 illustrate the abundance and preservation of diatoms, which occur only in upper Pliocene and Pleistocene sediments at Site 646 (the upper $330 \mathrm{mbsf}$ ). In this interval, the diatom preservation and abundance can be divided into three units (Fig. 4). The diatom preservation and abundance in Unit I (0-60 mbsf) and Unit III (150-330 mbsf) vary and most likely reflect changes in surface-water productivity. In Unit II (60-150 mbsf), diatoms are absent or rare and generally have poor preservation. The decrease in abundance and preservation in this unit may result from increased dissolution of biogenic silica. Diatoms do not occur in samples examined below 330 mbsf.

\section{Biostratigraphy}

We observed both primary and secondary biostratigraphic markers in the upper $330 \mathrm{~m}$ of Site 646; however, the generally poor diatom preservation observed in Unit II limits the stratigraphic reliability of several of these markers. Species observed in this interval are listed in Table 2.

The last occurrence of Rhizosolenia curvirostris, observed in Sample 105-646A-3H-1, 128-130 cm (17 mbsf), allows the stratigraphic interval above this sample to be assigned to the Denticulopsis seminae Zone of Koizumi (1973). In the North Pacific, the last occurrence of $R$. curvirostris is calibrated to the uppermost portion of the Brunhes Chron and has an estimated age of $0.276 \mathrm{Ma}$ (Morley et al., 1982). The correlation of this event to the magnetostratigraphy completed for Site 646 (Clement et al., this volume) also places the last occurrence of this species in the upper part of the Brunhes Chron and results in an estimated age of $0.27 \mathrm{Ma}$. This interval can also be assigned to the uppermost part of the Pseudoeunotia doliolus Zone, as used by Baldauf (1987) in the North Atlantic.

Although the occurrence of Actinocyclus oculatus at Site 646 is sporadic, the occurrence of this species in Sample 105-646A$9 \mathrm{H}-5,98-100 \mathrm{~cm}$ ( $83 \mathrm{mbsf}$ ), suggests that the interval from Sample 105-646A-3H-1, 128-130 cm, to Sample 105-646A-9H-5, 98$100 \mathrm{~cm}$ (17-83 mbsf), may be equivalent to the Rhizosolenia curvirostris Zone of Koizumi (1973). The last occurrence of $A$. oculatus in the North Pacific is placed between 1.3 and $0.8 \mathrm{Ma}$, depending on the geographic location (Koizumi and Tanimura, 1985; Sancetta and Silvestri, 1984, 1986). Koizumi (1973) defined two subzones for the $R$. curvirostris Zone separated by the last occurrence of Nitzschia reinholdii. In the North Pacific, this event is dated at $0.47-0.52 \mathrm{Ma}$ by Koizumi and Tanimura (1985), at $0.65 \mathrm{Ma}$ by Barron (1985a), and at $0.6 \mathrm{Ma}$ by Sancetta and Silvestri (1986). In the North Atlantic, this event has an estimated age of $0.44 \mathrm{Ma}$ (Baldauf, 1987).

At Site 646, the last occurrence of $N$. reinholdii is tentatively placed in Sample 105-646A-7H-5, 120-122 cm (62 mbsf). However, the stratigraphic placement of this event is unreliable because of the sporadic occurrence of this species and the poor diatom preservation. The stratigraphic uncertainty is further demonstrated by the first occurrence of Pseudoeunotia doliolus, which at Site 646 coincides with the last occurrence of $N$. reinholdii. In the equatorial Pacific (Barron, 1985a) and elsewhere in the North Atlantic (Baldauf, 1987), the first occurrence of $P$. doliolus $(1.8 \mathrm{Ma})$ falls well below that of the last occurrence of $N$. reinholdii.
The fairly consistent occurrence of Stephanopyxis horridus in the interval from Sample 105-646B-17X, CC, to 105-646B$22 \mathrm{X}-4,50-52 \mathrm{~cm}(159.1-202 \mathrm{mbsf})$, suggests that this interval is equivalent to the Denticulopsis seminae var. fossilis Zone of Koizumi (1973). However, the stratigraphic range of this species may be diachronous between its occurrence at Site 646 and that in the North Pacific. Barron (1985a) indicates that the range of $S$. horridus approximates the limits of the $D$. seminae var. fossilis Zone. Therefore, in the Pacific the range of this species extends from the top of the Gauss Chron to within the Olduvai Subchron and has an estimated age of 2.4-1.7 Ma. At Site 646, the range of $S$. horridus extends from the uppermost Gauss to the lower portion of the Matuyama Chron, thereby having an estimated age of 2.6-2.2 Ma. The upper limit of this species may be preservationally controlled. Barron (1985a) also indicates that the last occurrence of Thalassiosira zabelinae is within the $D$. seminae var. fossilis Zone in the North Pacific. The last occurrence of this species at Site 646 is in Sample 105-646B$11 \mathrm{H}, \mathrm{CC}(101.4 \mathrm{mbsf})$, indicating that this event is much younger (1.2 Ma) at this site than in the North Pacific (2.4-1.7 Ma; Barron, 1985a).

The occurrence of Thalassiosira zabelinae and Cosmiodiscus insignis in Cores 105-646B-31X (284.7 mbsf) through 105-646B$35 \mathrm{X}$ (333.1 mbsf) suggests a Pliocene age for this interval. In the North Pacific, the stratigraphic range of $T$. zabelinae extends from the lower part of subzone b of the Denticulopsis kamtschatica Zone (latest Miocene) to the middle part of the Denticulopsis seminae var. fossilis Zone (middle late Pliocene; Barron, 1985a), and that of Cosmiodiscus insignis extends from the middle part of subzone b of the Denticulopsis hustedtii Zone (latest Miocene) to the top of subzone b of the Denticulopsis kamtschatica Zone (earliest Pliocene; Barron, 1985a). The stratigraphic occurrence of $C$. insignis at Site 646 is restricted between Samples 105-646B-31X-4, 123-125 cm (290 mbsf), to $105-646 \mathrm{~B}-35 \mathrm{X}-2,123-125 \mathrm{~cm}$ (332 mbsf), the last occurrence of this species being correlated with the upper part of the Gilbert Chron, late early Pliocene. Therefore, the last occurrence ranges stratigraphically younger at this site than in the North Pacific.

\section{Paleoenvironment}

The diatom assemblage observed at Site 646 can be divided into three components: a high-latitude coastal assemblage, a high-latitude pelagic assemblage, and a warm-temperate assemblage. The high-latitude coastal assemblage is characterized by Melosira sol, Nitzschia grunowii, N. cylindra, Porosira glacialis, and Thalassiosira gravida. The high-latitude pelagic assemblage consists of Actinocyclus oculatus, Denticulopsis seminae, Rhizosolenia curvirostris, Stephanogonia hanzawae, Stephanopyxis horridus, Thalassiosira nidulus, and T. antiqua. The warmtemperate assemblage includes Nitzschia reinholdii and Pseudoeunotia doliolus. The abundance of these species varies throughout the stratigraphic sequence, most likely in response to changing surface-water conditions. The present sample resolution does not permit an interpretation of how surface circulation responded to climatic fluctuations.

The Denticulopsis seminae group consists of varieties of $D$. seminae common in North Pacific and Bering Sea upper Pliocene to Holocene sediments. Baldauf $(1984,1986,1987)$ indicated that this group is geographically restricted in the North Atlantic Ocean (DSDP Sites 410, 552, 607, and 609-611) and has a shorter temporal range than in the North Paciflc. Within the North Atlantic, the $D$. seminae group was recorded in sediments representing an interval from about 1.1 to about $0.7 \mathrm{Ma}$ (Baldauf, 1984, 1986, 1987). At Site 646, the first occurrence of the $D$. seminae group is earlier than in other North Atlantic sites, at about 1.7 Ma. Baldauf $(1986,1987)$ discussed the sig- 
Table 2. Chart of occurrences of selected species, showing abundance and preservation.

\begin{tabular}{|c|c|c|c|c|c|c|c|c|c|c|c|c|}
\hline $\begin{array}{l}\text { Core, section, } \\
\text { interval }(\mathrm{cm})\end{array}$ & 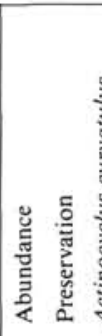 & 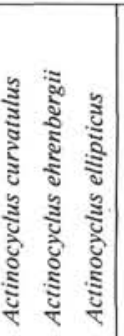 & 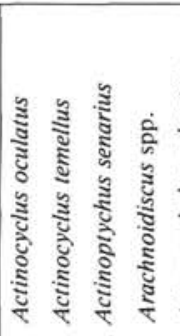 & 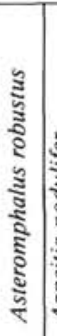 & 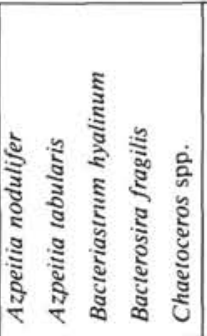 & 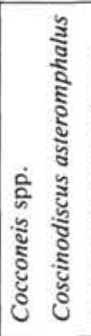 & 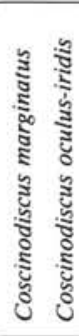 & 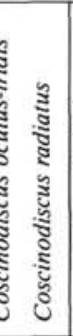 & 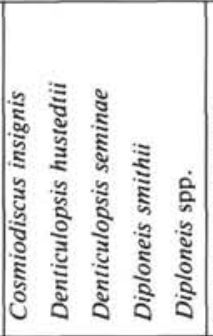 & 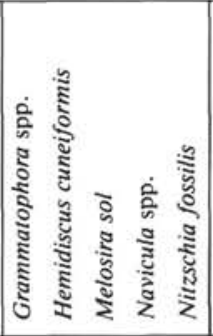 & 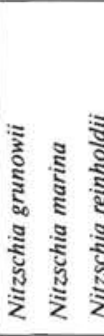 & 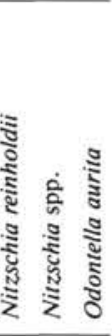 \\
\hline $\begin{array}{r}105-646 \mathrm{~A}-1 \mathrm{H}-1,124-126 \\
646 \mathrm{~A}-1 \mathrm{H}-2,124-126 \\
646 \mathrm{~A}-1 \mathrm{H}, \mathrm{CC} \\
646 \mathrm{~A}-3 \mathrm{H}-1,128-130 \\
646 \mathrm{~A}-3 \mathrm{H}-2,128-130\end{array}$ & $\begin{array}{ll}\mathrm{C} & \mathrm{M} \\
\mathrm{F} & \mathrm{P} \\
\mathrm{C} & \mathrm{P} \\
\mathrm{C} & \mathrm{M} \\
\mathrm{C} & \mathrm{M}\end{array}$ & $\begin{array}{ll}R & \\
R & \\
F & \\
F & \\
F & F\end{array}$ & R & $\mathbf{R}$ & $\begin{array}{l}R \\
R \\
R\end{array}$ & $\mathbf{R}$ & $\begin{array}{ll}\mathrm{F} & \mathrm{R} \\
& \mathrm{R} \\
\mathrm{F} & \\
\mathrm{F} & \\
\mathrm{F} & \end{array}$ & $\begin{array}{ll}R & F \\
R & \\
& F\end{array}$ & & ${ }^{R}{ }_{R} R$ & $\mathrm{R}$ & \\
\hline $\begin{array}{l}\text { 646A-3H-3, } 128-130 \\
646 \mathrm{~A}-3 \mathrm{H}-4,128-130 \\
646 \mathrm{~A}-3 \mathrm{H}, \mathrm{CC} \\
646 \mathrm{~A}-5 \mathrm{H}-1,120-122 \\
646 \mathrm{~A}-5 \mathrm{H}-2,120-122\end{array}$ & $\begin{array}{ll}\mathrm{R} & \mathrm{M} \\
\mathrm{C} & \mathrm{M} \\
\mathrm{F} & \mathrm{M} \\
\mathrm{A} & \mathrm{M} \\
\mathrm{C} & \mathrm{M}\end{array}$ & $\begin{array}{ll}R & \\
F & \\
R & \\
F & R\end{array}$ & & & $\begin{array}{l}C \\
\mathrm{R} \\
\mathrm{C} \\
\mathrm{F}\end{array}$ & $\begin{array}{l}\mathrm{R} \\
\mathrm{R}\end{array}$ & $\begin{array}{l}\mathrm{R} \\
\mathrm{F} \\
\mathrm{F} \\
\mathrm{F}\end{array}$ & & R & & $\mathbf{R}$ & \\
\hline $\begin{array}{l}\text { 646A-5H-3, 120-122 } \\
\text { 646A-5H-4, 120-122 } \\
\text { 646A-5H-5, 119-121 } \\
\text { 646A-5H, CC } \\
\text { 646A-6H-1, 51-53 }\end{array}$ & $\begin{array}{ll}\mathrm{A} & \mathrm{M} \\
\mathrm{C} & \mathrm{P} \\
\mathrm{C} & \mathrm{P} \\
\mathrm{F} & \mathrm{P} \\
\mathrm{F} & \mathrm{M} \\
\end{array}$ & $\begin{array}{ll}F & \\
F & \\
R & F \\
F & \end{array}$ & & & $\begin{array}{l}F \\
R \\
F\end{array}$ & $\mathrm{R}$ & $\begin{array}{l}\mathrm{F} \\
\mathrm{F} \\
\mathrm{F} \\
\mathrm{R}\end{array}$ & & & & R & \\
\hline $\begin{array}{l}\text { 646A-6H-7, 29-31 } \\
\text { 646A-7H-5, 120-122 } \\
\text { 646A-7H, CC } \\
\text { 646A-9H-1, 96-98 } \\
\text { 646A-9H-4, 97-99 }\end{array}$ & $\begin{array}{ll}\mathrm{R} & \mathrm{P} \\
\mathrm{C} & \mathrm{G} \\
\mathrm{R} & \mathrm{P} \\
\mathrm{R} & \mathrm{P} \\
\mathrm{R} & \mathrm{P} \\
\end{array}$ & $R$ & & $\mathrm{R}$ & & & $\begin{array}{l}\mathrm{F} \\
\mathrm{R} \\
\mathrm{R} \\
\mathrm{R}\end{array}$ & & R & & $\mathrm{R}$ & $\mathbf{R}$ \\
\hline $\begin{array}{l}\text { 646A-9H-5, 98-100 } \\
646 \mathrm{~A}-9 \mathrm{H}, \mathrm{CC} \\
646 \mathrm{~A}-10 \mathrm{H}-3,50-52 \\
646 \mathrm{~B}-2 \mathrm{H}-3,5-7 \\
\text { 646B-2H-5, 141-143 }\end{array}$ & $\begin{array}{ll}\mathrm{R} & \mathrm{M} \\
\mathrm{R} & \mathrm{M} \\
\mathrm{R} & \mathrm{M} \\
\mathrm{C} & \mathrm{M} \\
\mathrm{R} & \mathrm{M} \\
\end{array}$ & $\begin{array}{l}\mathrm{R} \\
\mathrm{R} \\
\mathrm{R}\end{array}$ & $\begin{array}{l}\mathrm{R} \\
\mathrm{R}\end{array}$ & & R & & $\begin{array}{l}\mathrm{R} \\
\mathrm{R} \\
\mathrm{R} \\
\mathrm{R} \\
\mathrm{R}\end{array}$ & & $\begin{array}{l}\mathrm{R} \\
\mathrm{R} \\
\mathrm{R}\end{array}$ & & R & $\mathbf{R}$ \\
\hline $\begin{array}{l}\text { 646B-2H, CC } \\
646 \mathrm{~B}-4 \mathrm{H}-3,19-21 \\
646 \mathrm{~B}-4 \mathrm{H}-3,140-142 \\
646 \mathrm{~B}-4 \mathrm{H}, \mathrm{CC} \\
646 \mathrm{~B}-10 \mathrm{H}, \mathrm{CC}\end{array}$ & $\begin{array}{ll}\mathrm{C} & \mathrm{P} \\
\mathrm{C} & \mathrm{M} \\
\mathrm{C} & \mathrm{M} \\
\mathrm{A} & \mathrm{M} \\
\mathrm{R} & \mathrm{P} \\
\end{array}$ & $\begin{array}{ll}\mathrm{R} & \\
\mathrm{R} & \mathrm{R} \\
\mathrm{R} & \\
\mathrm{R} & \\
& \end{array}$ & & & R & & $\begin{array}{l}\mathrm{R} \\
\mathrm{C} \\
\mathrm{R} \\
\mathrm{R} \\
\mathrm{R}\end{array}$ & & & $\mathbf{R}$ & $R$ & \\
\hline $\begin{array}{l}646 \mathrm{~B}-11 \mathrm{H}-1,124-126 \\
646 \mathrm{~B}-11 \mathrm{H}-2,124-126 \\
646 \mathrm{~B}-11 \mathrm{H}-4,124-126 \\
646 \mathrm{~B}-11 \mathrm{H}-5,116-118 \\
646 \mathrm{~B}-11 \mathrm{H}-6,124-126\end{array}$ & $\begin{array}{ll}R & P \\
R & P \\
R & P \\
F & P \\
R & P\end{array}$ & & $\mathbf{R}$ & & & & $\begin{array}{l}\mathrm{R} \\
\mathrm{R} \\
\mathrm{R}\end{array}$ & & & $\mathrm{R}$ & R & \\
\hline $\begin{array}{l}646 \mathrm{~B}-12 \mathrm{H}-2,50-52 \\
646 \mathrm{~B}-12 \mathrm{H}-4,50-52 \\
646 \mathrm{~B}-12 \mathrm{H}, \mathrm{CC} \\
646 \mathrm{~B}-13 \mathrm{H}-1,124-126 \\
646 \mathrm{~B}-13 \mathrm{H}-4,114-116\end{array}$ & $\begin{array}{ll}\mathrm{F} & \mathrm{M} \\
\mathrm{R} & \mathrm{M} \\
\mathrm{R} & \mathrm{P} \\
\mathrm{R} & \mathrm{P} \\
\mathrm{C} & \mathrm{M}\end{array}$ & C & & & & & $\begin{array}{ll}\mathrm{R} & \mathrm{R} \\
& \\
\mathrm{R} & \\
\mathrm{R} & \end{array}$ & $\mathrm{R}$ & & & & $\mathrm{R}$ \\
\hline $\begin{array}{l}646 \mathrm{~B}-13 \mathrm{H}, \mathrm{CC} \\
646 \mathrm{~B}-14 \mathrm{H}-1,124-126 \\
646 \mathrm{~B}-14 \mathrm{H}-3,124-126 \\
646 \mathrm{~B}-14 \mathrm{H}-4,48-50 \\
646 \mathrm{~B}-14 \mathrm{H}-4,124-126\end{array}$ & $\begin{array}{ll}\mathrm{R} & \mathrm{P} \\
\mathrm{R} & \mathrm{P} \\
\mathrm{R} & \mathrm{P} \\
\mathrm{R} & \mathrm{P} \\
\mathrm{R} & \mathrm{P}\end{array}$ & & & & & & $\mathrm{R}$ & & & R & & \\
\hline $\begin{array}{l}\text { 646B-14H-5, 124-126 } \\
646 \mathrm{~B}-14 \mathrm{H}-6,48-50 \\
646 \mathrm{~B}-16 \mathrm{X}, \mathrm{CC} \\
646 \mathrm{~B}-17 \mathrm{X}, \mathrm{CC} \\
646 \mathrm{~B}-18 \mathrm{X}-1,124-126 \\
\end{array}$ & $\begin{array}{ll}\mathrm{R} & \mathrm{P} \\
\mathrm{R} & \mathrm{P} \\
\mathrm{F} & \mathrm{M} \\
\mathrm{R} & \mathrm{P} \\
\mathrm{R} & \mathrm{P} \\
\end{array}$ & $\begin{array}{l}\mathrm{R} \\
\mathrm{R}\end{array}$ & R & & & & $\begin{array}{ll}\mathrm{R} & \mathrm{R} \\
\mathrm{R} & \\
\mathrm{R} & \\
\end{array}$ & R & & $\begin{array}{l}\mathrm{R} \\
\mathrm{R} \\
\mathrm{R}\end{array}$ & & \\
\hline $\begin{array}{l}\text { 646B-18X-2, 17-19 } \\
\text { 646B-18X-3, 18-19 } \\
\text { 646B-18X-3, 65-67 } \\
\text { 646B-18X, CC } \\
\text { 646B-19XX, CC }\end{array}$ & $\begin{array}{ll}R & P \\
R & P \\
R & P \\
R & P \\
R & P\end{array}$ & $R$ & & & & & & & & $\mathbf{R}$ & & \\
\hline $\begin{array}{l}\text { 646B-20X-1, 36-38 } \\
646 \mathrm{~B}-20 \mathrm{X}-2,36-38 \\
646 \mathrm{~B}-20 \mathrm{X}-3,36-38 \\
646 \mathrm{~B}-20 \mathrm{X}, \mathrm{CC} \\
646 \mathrm{~B}-21 \mathrm{X}-1,130-132\end{array}$ & $\begin{array}{ll}A & G \\
F & P \\
F & P \\
R & P \\
R & P \\
\end{array}$ & $\begin{array}{l}\mathrm{F} \\
\mathrm{R}\end{array}$ & R & $\mathbf{R}$ & $R$ & $\mathbf{R}$ & $\begin{array}{ll}\mathrm{R} & \mathrm{R} \\
\mathrm{R} & \mathrm{R} \\
\mathrm{R} & \\
\mathrm{R} & \end{array}$ & & & $R$ & $\mathrm{R}$ & \\
\hline $\begin{array}{l}646 \mathrm{~B}-21 \mathrm{X}-2,130-132 \\
646 \mathrm{~B}-21 \mathrm{X}-3,130-132 \\
646 \mathrm{~B}-21 \mathrm{X}-4,130-132\end{array}$ & $\begin{array}{ll}R & P \\
F & M \\
R & M\end{array}$ & R & & & $\mathrm{R}$ & R & $\mathbf{R}$ & & & & & \\
\hline
\end{tabular}


Table 2 (continued).

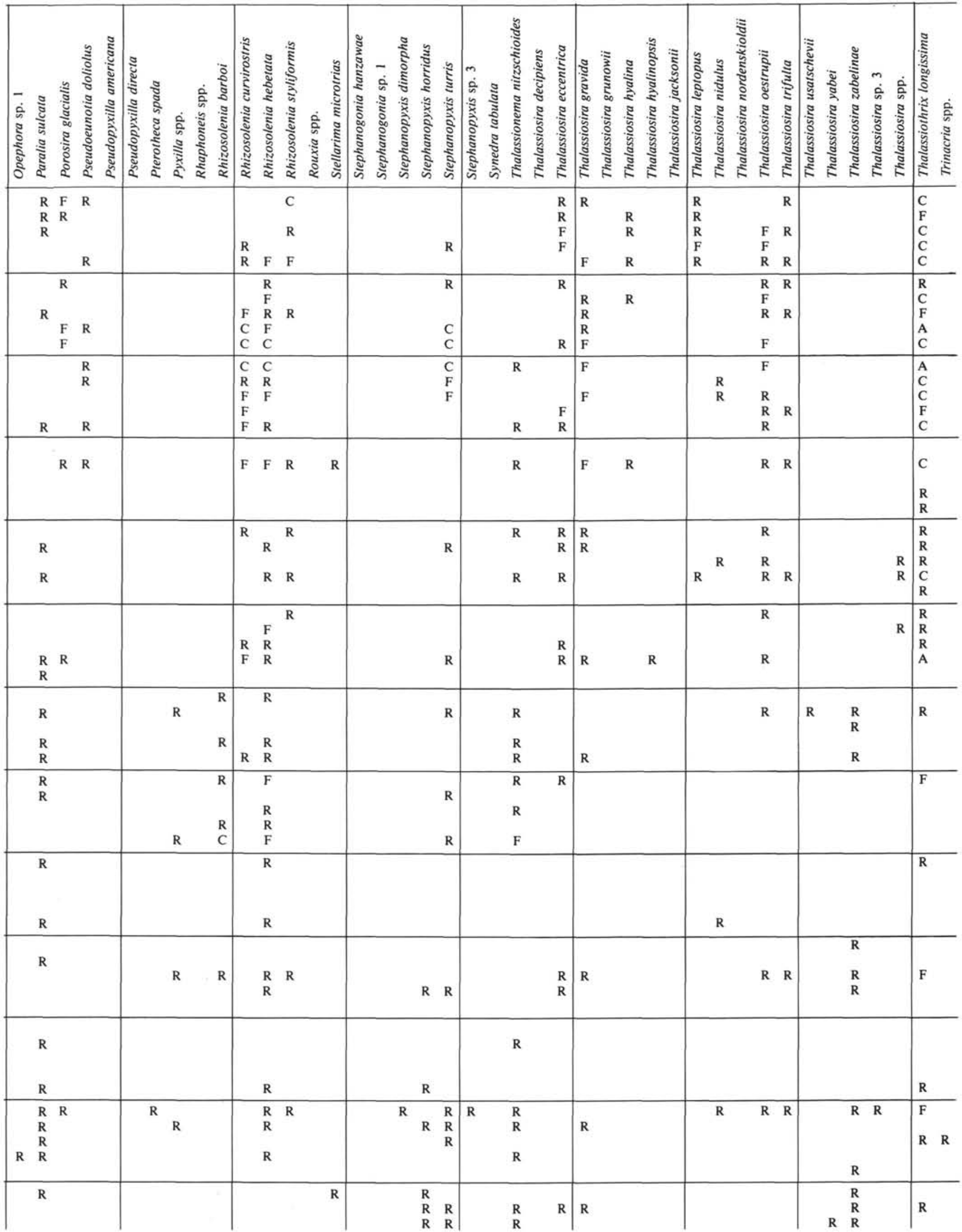


Table 2 (continued).

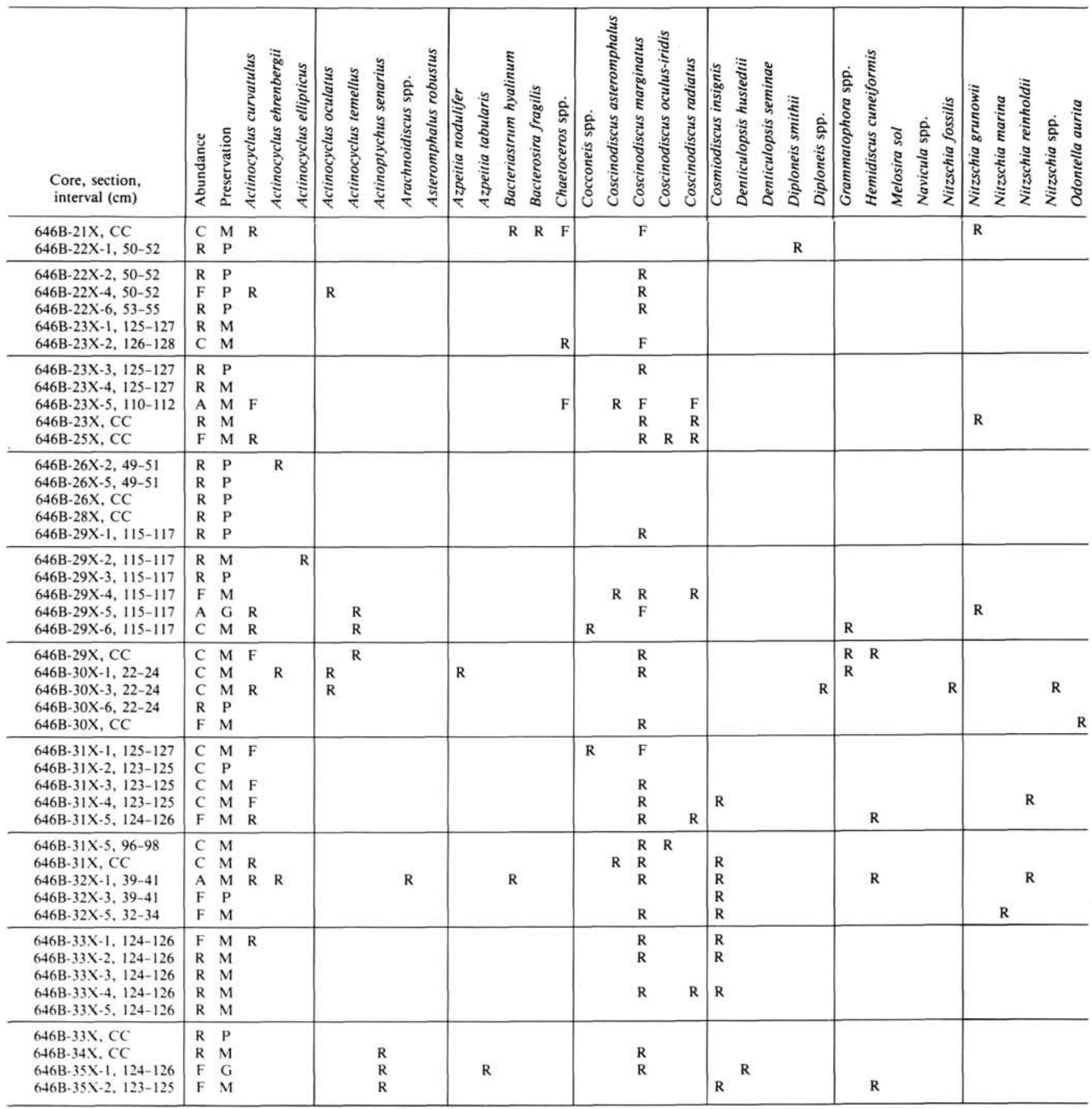

Abundance, $\mathrm{A}=$ abundant, $\mathrm{C}=$ common, $\mathrm{F}=$ few, $\mathrm{R}=$ rare, $\mathrm{B}=$ barren; preservation, $\mathrm{G}=$ good, $\mathrm{M}=$ moderate, $\mathrm{P}=$ poor.

nificance of this group in the North Atlantic Ocean in detail. The older occurrence of the $D$. seminae group in the Labrador Sea suggests that this group may have been restricted to this region and spread from there to elsewhere in the North Atlantic during favorable climatic and oceanographic conditions.

\section{CONCLUSION}

The reliability of diatom stratigraphic markers was limited at Sites 645 and 646 because of the poor preservation of most samples and the difficulty of using existing zonations outside their geographic limits. Nevertheless, the study of the diatom assemblages of these two sites is rich in paleoenvironmental information. At Site 645 , some diatoms occurring in the sediments are typical of the summer pack-ice assemblages of Baffin Bay, and others are characteristic of the Baffin Island shelf. Therefore, some of the diatoms preserved in the sediment at Site 645 came from the shelf and were transported by turbidity currents down the continental slope. The Site 646 diatom assemblage contains a mixture of high-latitude neritic and pelagic diatoms with some species characteristic of more temperate waters. 
Table 2 (continued).

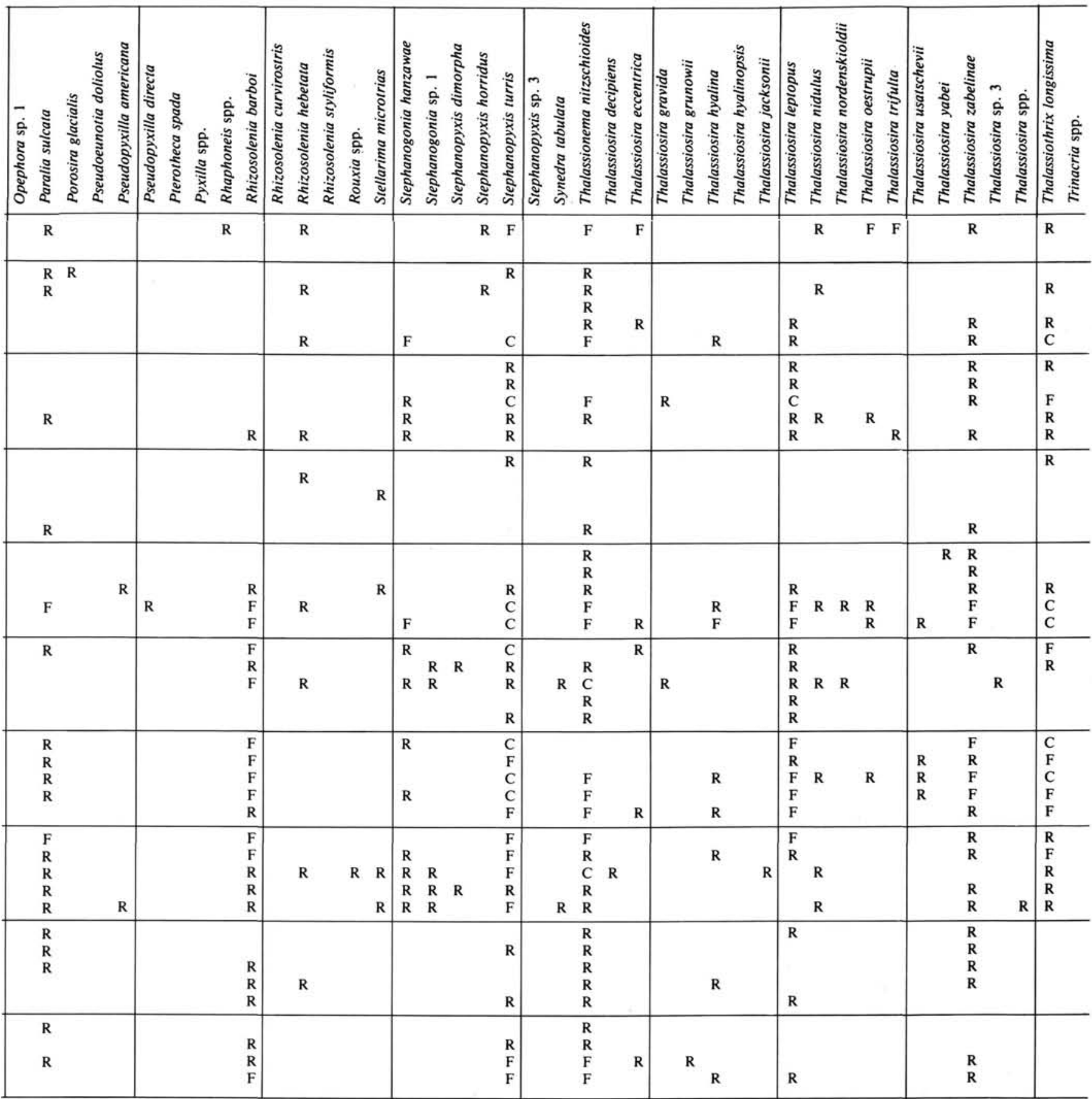

\section{ACKNOWLEDGMENTS}

We thank W. Abbott and C. Sancetta for reviewing this manuscript; M. Arthur and S. Srivastava, the co-chief scientists of Leg 105; B. Clement, the staff scientist; and all those who participated in Leg 105 during that enjoyable and productive cruise. We also thank the French Ocean Drilling Program and the USSAC for their financial support. The National Science Foundation provided the samples.

\section{REFERENCES}

Abbott, W. H., and Andrews, G. W., 1979. Middle Miocene marine diatoms from the Hawthorn Formation of the Ridgeland Trough, South Carolina and Georgia. Micropaleontology, 25:225-271.
Agardh, C. A., 1832. Conspectus Criticus Diatomacearum: Lundae, Pt. IV:48-66.

Akiba, F., 1986. Middle Miocene to Quaternary diatom biostratigraphy in the Nankai Trough and Japan Trench, and modified lower Miocene through Quaternary diatom zones for middle-to-high latitudes of the North Pacific. In Kagami, H., Karig, D. E., Coulbourn, W. C., et al., Init. Repts. DSDP, 87: Washington (U.S. Govt. Printing Office), 393-481.

Akiba, F., and Yanagisawa, Y., 1986. Taxonomy, morphology and phylogeny of the Neogene diatom zonal marker species in the middle-tohigh latitudes of the North Pacific. In Kagami, H., Karig, D. E., Coulbourn, W. C., et al., Init. Repts. DSDP, 87: Washington (U.S. Govt. Printing Office), 483-554. 
Andrews, G. W., 1976. Miocene marine diatoms from the Choptank Formation, Calvert County, Maryland. U.S. Geol. Surv., Prof. Pap., 910:1-26.

Andrews, G. W., and Abbott, W. H., 1985. Miocene diatoms from the Hawthorn Formation, Thomas County, Georgia. Bull. Am. Paleontol., 87:57-109.

Bailey, J. W., 1856. Notice of microscopic forms found in the soundings of the Sea of Kamchatka. Am. J. Sci. Arts, ser. 2, 22:1-6.

Baldauf, J. G., 1982. Identification of the Holocene-Pleistocene boundary in the Bering Sea by diatoms. Boreas, 11:113-118.

1984. Cenozoic diatom biostratigraphy and paleoceanography of the Rockall Plateau Region, North Atlantic, Deep Sea Drilling Project Leg 81. In Roberts, D., Schnitker, D., et al., Init. Repts. DSDP, 81: Washington (U.S. Govt. Printing Office), 439-478.

1986. Diatom biostratigraphic and paleoceanographic interpretations for the middle to high latitude North Atlantic Ocean. In Summerhayes, C. P., and Shackleton, N. J. (Eds.), North Atlantic Paleoceanography, Geol. Soc. (London) Spec. Publ., 21:243-252.

1987. Diatom biostratigraphy of the middle and high latitude North Atlantic Ocean, Deep Sea Drilling Project Leg 94. In Ruddiman, W., Kidd, R., et al., Init. Repts. DSDP, 94: Washington (U.S. Govt. Printing Office), 729-762.

Baldauf, J. G., and Barron, J. A., 1982. Diatom biostratigraphy and paleoecology of the type section of the Lusian Stage, central California. Micropaleontology, 28:59-84.

Barron, J. A., 1975. Late Miocene-early Pliocene marine diatoms from southern California. Palaeontographica, 151(B):97-170.

1980. Lower Miocene to Quaternary diatom biostratigraphy of Leg 57, off Northeastern Japan. In Scientific Party, Init. Repts. DSDP 56, 57 (Pt. 2): Washington (U.S. Govt. Printing Office), 641691.

1985a. Miocene to Holocene planktic diatoms. In Bolli, H. M., Saunders, J. B., and Perch-Nielsen, K. (Eds.), Plankton Stratigraphy: Cambridge (Cambridge Univ. Press), 763-810.

1985b. Late Eocene to Holocene diatom biostratigraphy of the equatorial Pacific Ocean, Deep Sea Drilling Project Leg 85. In Mayer, L., Thayer, F., Thomas, E., et al., Init. Repts. DSDP, 85: Washington (U.S. Govt. Printing Office), 413-456.

Barron, J. A., and Baldauf, J.G., 1986. Diatom stratigraphy of the lower Pliocene part of the Sisquoc Formation, Harris Grade section, California. Micropaleontology, 32:357-371.

Barron, J. A., Keller, G., and Dunn, D. A., 1985. A multiple microfossil biochronology for the Miocene. Geol. Soc. Am. Mem., 163:2136.

Berggren, W. A., Kent, D. V., and Van Couvering, J. A., 1985. Neogene geochronology and chronostratigraphy. In Snelling, N. J. (Ed.), Geochronology and the Geologic Time Scale, Geol. Soc. (London) Mem., 10:211-260.

Brébrisson, A., 1854. Note sur quelques Diatomées marines rares ou peu connues du littoral de Cherbourg. Mem. Soc. Nat. Sci. Cherbourg, 2:241-256.

Brébrisson, A., and de Godey, 1835. Algues des environs de Falaise. Mem. Soc. Acad. Art. Belles Lett. Falaise, 1-66, 256-269.

Brightwell, T., 1858. Remarks on the genus Rhizolenia of Ehrenberg. $Q$. J. Microsc. Sci., 6:1-93.

Brun, J., 1891. Diatomées espèces nouvelles marines, fossiles ou pélagiques. Mem. Soc. Phys. Hist. Nat. Genève, 31:1-47.

1894. Espèces nouvelles. Le Diatomiste, 2:72-78, 86-88.

Brun, J., and Tempère, J., 1889. Diatomées fossiles du Japon. Espèces marines et nouvelles des Calcaires Argileux de Sendai et de Yendo. Mém. Soc. Phys. Hist. Nat. Genève, 30:1-75.

Castracane, C. A., 1875. Contribuzione alla fiorula delle Diatomee del Mediterraneo ossia esame del contenuto dello stomaco di una Salpa pinnita, pescata a Messina. Atti Accad. Pontif. Neovi Lincei (Roma), 28:377-296.

Cleve, P. T., 1873. Examination of diatoms found on the surface of the Sea of Java. Bihang. Sven. K. Vetenskapsakad. Handl., 11:1-13.

1883. Diatoms collected during the expedition of the Vega. Ur Vega Exped. Vetensk. Iakttagelser, 3:457-517.

1894. Sur quelques espèces nouvelles ou peu connues. $L e$ Diatomiste, 2:143-147.

1896. Diatoms from Baffin Bay and Davis Strait. Bihang. $K$.

Sven. Vetenskapsakad. Handl., 22:1-22.

1903-1904. Plankton table for the North Sea. Bull. Coun.

Perm. Int. pour l'Exploration de la Mer, 1-216.
Cleve, P. T., and Grunow, A., 1880. Beiträge zur Kenntniss der arktischen Diatomeen. Bihang. K. Sven. Vetenskapsakad. Handl., 17:1120.

Cleve-Euler, A., 1941. Alttertiäre Diatomeen und Silicoflagellaten in inneren Schwedens, gefunden und gezeichnet von Åke Berg, beschreiben von Astrid Cleve-Euler. Palaeontographica, 92(A):165-212.

Dzinoridze, R. N., Jousé, A. P., Koroleva-Golikova, G. S., Kozlova, G. E., Nagaeva, G. S., Petrushevskaya, M. G., and Strelnikova, N. I., 1978. Diatom and radiolarian Cenozoic stratigraphy, Norwegian $\mathrm{Ba}-$ sin, DSDP Leg 38. In Talwani, M., Udintsev, G., et al., Init. Repts. DSDP, Suppl. to Vols. $38,39,40$, and 41 : Washington (U.S. Govt. Printing Office), 289-427.

Ehrenberg, C. G., 1838. Die Infusionstierchen als vollkommende Organismen, Ein Blick in das tiefere organische Leben der Natur: Leipzig (Leopold Voss).

1839. Uber nach jetzt zahlreich lebende Thierarten der Kreidebildung und den Organismus der Polythalamien. Abh. K. Akad. Wiss. Berlin, 81-174.

1841. Uber Verbreitung und Einfluss des mikroskopïschen Lebens in Süd- und Nord-Amerika. Ber. Bekanntm. Geeign. Verh. K. Akad. Wiss. Berlin, 139-141.

1841 (1843). Verbreitung und Einfluss das mikroskopïschen Lebens in Süd- und Nord-Amerika. Abh. K. Akad. Wiss. Berlin, 1: 291-445.

1844a. Mitteilung über 2 neue Lager von Gebirgsmassen aus Infusorien als Meeres-Absatz in Nord-Amerika und eine Vergleichung derselben mit den organischen Kreide-Gebilden in Europa und Afrika. Abh. K. Akad. Wiss. Berlin, 57-97.

1844B. Einige vorläufige Resultate seiner Untersuchungen der ihm der von der Südpolreise des Capitain Ross, so wie von den Herren Schayer und Darwin zugekommenen Materialien über das verhalten des kleinsten Lebens in den Ozeanen und den grössten bisher zugänglichen Tiefen des Weltmeers. Ber. Bekanntm. Geeign. Verh. K. Akad. Wiss. Berlin, 182-207.

1854. Mikrogeologie das Erden und Felsen schaffende Wirken des unsichtbar kleinen selbständigen Lebens auf der Erde: Leipzig (Leopold Voss).

Fenner, J., 1978. Cenozoic diatom biostratigraphy of the equatorial and southern Atlantic Ocean. In Perch-Nielsen, K., Supko, P. R., et al., Init. Repts. DSDP, Suppl. to Vols. 38, 39, 40, and 41: Washington (U.S. Govt. Printing Office), 491-623.

Forti, D. A., 1909. Studi per una monografia del genere Pyxilla (Diatomee) e dei generi affini. Nuova Notarisia, 20:5-24.

Frenguelli, I., 1949. Diatomeas fosiles de los yacimientos chilenos de iltil y Mejillones. Darwiniana, 9:97-157.

Fryxell, G. A., and Hasle, G. R., 1972. Thalassiosira eccentrica (Ehrenb.) Cleve, $T$. symmetrica sp. nov., and some related centric diatoms. $J$. Phycol., 8:297-317.

1973. Coscinodiscineae: some consistent patterns in the diatom morphology. Nova Hedwigia, Beift., 45:69-96.

1979. The genus Thalassiosira: T. trifulta sp. nova and other species with tricolumnar supports on strutted processes. Nova Hedwigia, Beift., 64:13-31.

Fryxell, G. A., Sims, P. A., and Watkins, T. P., 1986. Azpeitia (Bacillariophyceae): related genera and promorphology. Syst. Bot. Monogr., 13:1-74.

Gran, H. H., 1897. Protophyta: Diatomaceae, Silicoflagellata og Cilioflagellata. Botanik, Den Norske Nordhavs-Expedition 1876-1878, Vol. 24: Christiania (Grondahl and Sons), 1-36.

1900. Bemerkungen über einige Planktondiatomeen. Nyt. Mag. Naturv. (Christiania), 38:103-126.

1904. Diatomaceae from ice floes and plankton of the Arctic Ocean. In Nansen, F. (Ed.) The Norwegian North Polar Expedition 1893-1896, Vol. 4: Christiania (Grondahl and Sons), 1-74.

Gregory, W., 1857. On new forms of marine Diatomaceae found in the Firth of Clyde and in Loch Fyne, illustrated by numerous figures drawn by R. K. Greville. Trans. R. Soc. Edinburgh, 21:473-542.

Grunow, A., 1862. Die österreichischen Diatomaceen nebst Anschluss einiger neuen Arten von andern Lokalitaten und einer kritischen Uebersicht der bischer bekannten Gattungen und Arten. Erste Foge, Epithemieae, Meridioneae, Diatomeae, Entopyleae, Surirelleae, Amphipleureae. Verh. Zool. Bot. Ges. Wien, 12:315-472.

1878. Alguen und Diatomaceen aus dem Kaspischen Meere. Beitr. Kenn. Kaukasusländer. Sitzungsber. Nat. Ges. "Isis" Dresden, 1-36; separate printing, 100-133. 
1884. Die Diatomeen von Franz-Josefs-Land. Denkschr. $K$. Akad. Wiss. Math. Naturwiss. Kl. Wien, 48:53-112. Hasle, G. R., 1960. Phytoplankton and silicate species from the tropical Pacific. Skrift. Nor. Vidensk. Akad. Kl. 1: Mat. Naturvidensk. Kl., 2:1-50. 1965. Nitzschia and Fragilariopsis species studied in the light and electron microscopes. III. The genus Fragilariopsis. Skrift. Nor. Vidensk. Akad. Kl. 1, Mat. Naturvidensk. Kl., 21:1-49.

1972. Fragilariopsis Hustedt as a section of the genus Nitzschia Hassall. Nova Hedwigia, Beift., 39:111-119.

Hasle, G. R., and Fryxell, G. A., 1977. The genus Thalassiosira: some species with a linear areola array. Nova Hedwigia, Beift., 54:15-66.

Hasle, G. R., and Sims, P. A., 1986. The diatom genera Stellarima and Symbolophora with comments on the genus Actinoptychus. Br. J. Phycol., 21:97-114.

Heiden, H., and Kolbe, R. W., 1927. Die marinen Diatomeen der deutschen Südpolarexpedition 1901-1903. Bot. Heft., 8:447-745.

Helmcke, J. G., and Krieger, W., 1954. Diatomeenschalen im elektronenmikroskopischen Bild. Bild Forsch. Abt. Biol. Berlin, 2:1-24.

Hendey, I. N., 1964. An introductory account of the smaller algae of British coastal waters. Pt. V: Bacillariophyceae (Diatoms). Fishery Invest., ser. IV:1-317.

Hustedt, F., 1927-1964. Die Kieselalgen Deutschlands, Oesterreichs und der Schweiz, mit Berücksichtigung der anderen Länder Europas sowie der angrenzenden Meeresgebiete. In Rabenhorst, L. (Ed.), Kryptogamen-Flora von Deutschland, Oesterreich und der Schweiz, Vol. 7: Leipzig (Akademie Verlag).

Jöergensen, E. G., 1905. The protist plankton and the diatoms in bottom samples. In Nordgaard, O. (Ed.), Hydrological and biological Investigations in Norwegian Fiords: Bergen (John Grieg).

Jousé (Zhuse), A. P., 1959. Principal development stages of marine diatoms of the far east in the Tertiary and Quaternary period. Bot. Zh. (Leningrad), 44:44-55.

1961. Miocene and Pliocene marine diatoms from the far east (in Russian). Bot. Mater. Otd. Spor. Rast. Inst. BIN AN SSSR, Izd. AN SSSR, Moscow-Leningrad, 16:59-70.

1962. Stratigraphic and paleographic studies in the northwestern part of the Pacific Ocean (in Russian). Okeanogr. Inst., Izd. Akad. Nauk. SSSR (Moscow), 1-358.

1968. New species of diatoms in bottom sediments of the Pacific and the Sea of Okhotsk. Nov. Syst. Plant. Non Vasc., Bot. Inst., Akad. Nauk. SSSR, 4:12-21.

, 1971. Species formaeque novae et curiosae Bacillariophytorum in sedimentis fundi Oceani Pacifici. Nov. System. Plant. Non Vasc., Bot. Inst., Akad. Nauk. SSSR, 8:12-18.

Kanaya, T., 1959. Miocene diatom assemblages from the Onnagawa Formation and their distribution in correlative formations in northeast Japan. Sci. Rep. Tohoku Univ., 2nd ser. (Geol.), 30: 1-130.

Koizumi, I., 1968. Tertiary diatom flora of Oga Peninsula, Akita Prefecture, northeast Japan. Sci. Rep. Tohoku Univ., 2nd ser. (Geol.), 40:170-240.

1972. Marine diatom flora of the Pliocene Tatsunokuchi Formation in the Fukushima Prefecture. Trans. Proc. Paleontol. Soc. Japan, n.s., 86:340-359.

1973. The late Cenozoic diatoms of Sites 183-193, Leg 19 , Deep Sea Drilling Project. In Creager, J. S., Scholl, D. W., et al., Init. Repts. DSDP, 19: Washington (U.S. Govt. Printing Office), 805-855.

1980. Neogene diatoms from the Emperor Seamount Chain, Leg 55, Deep Sea Drilling Project. In Jackson, E. D., Koizumi, I., et al., Init. Repts. DSDP, 55: Washington (U.S. Govt. Printing Office), 387-407.

Koizumi, I., and Tanimura, Y., 1985. Neogene diatom biostratigraphy of the middle latitude western north Pacific, Deep Sea Drilling Project Leg 86. In Heath, G. R., Burckle, L. H., et al., Init. Repts. DSDP 86: Washington (U.S. Govt. Printing Office), 269-300.

Kützing, F. T., 1844-1849. Die Kieselschaligen Bacillarien oder Diatomeen: Nordhausen.

Lauder, H. S., 1864. On new diatoms. Trans. Microsc. Soc. London, $12: 6-8$.

Lyngbye, H. G., 1819. Tentamen hydrophytologiae Danicae Continens omnia Hydrophyta Cryptogama Danicae, Holsatiae, Faeroae, Islandiae, Groenlandiae huiusque cognita, systematica disposita, descripta et iconibus illustrata, adjectis simul speciebus norvegicis. Hafniae, $1-248$.
Markham, W. E., 1981. Ice Atlas, Canadian Arctic Waterways: Quebec (Canadian Govt. Publishing Center).

Morley, J. J., Hays, J. D., and Robertson, J. H., 1982. Stratigraphic framework for the late Pleistocene in the northwest Pacific Ocean. Deep-Sea Res., 29:1485-1499.

Nikolaev, V. A., 1983. On the genus Symbolophora (Bacillariophyta) (in Russian). Bot. Zh., (Leningrad), 69:1123-1128.

Ostenfeld, C. H., 1900. Plankton. In Knudsen, M., and Ostenfeld, C. (Eds.), Iakttagelser over overfladevandets Temperature, Saltholdighed og Plankton pa a is landske og grunlandske Skibsrouter in 1899: Copenhagen (privately printed), 45-93.

Pantocsek, J., 1886. Marine Bacillarien. Pt. 1, Beitrage zur Kenntniss der fossilen Bacillarien Ungarns: Berlin (W. Junk). , 1889. Brackwasser Bacillarien. Pt. 2, Beïtrage zur Kenntniss der fossilen Bacillarien Ungarns: Berlin (W. Junk). , 1892. Süsswasser Bacillarien. Pt. 3, Beïtrage zur Kenntniss der fossilen Bacillarien Ungarns: Berlin (W. Junk).

Pergallo, H., and Pergallo, M., 1897-1908. Diatomées marines de France et des districts maritimes voisins, 2 vols.: Grez and Loing (Tempére); reprint: Amsterdam (A. Asher and Co.).

Pritchard, A., 1861. History of Infusoria, Living and Fossil. 4th ed., rev. and enl. by J. T. Arlidge, W. Archer, J. Ralfs, W. C. Williamson, and A. Pritchard: London (Whittaker and Co.).

Rattray, J., 1889. A revision of the genus Coscinodiscus and some allied genera. Proc. R. Soc. Edinburgh, 16:449-692.

Roper, F. C. S., 1858. Notes on some new species and varieties of British marine Diatomaceae. J. Queck. Microsc. Sci., 6:17-25.

Sancetta, C., 1982. Distribution of diatom species in surface sediments of the Bering and Okhotsk seas. Micropaleontology, 28:221-257.

Sancetta, C., and Silvestri, S. M., 1984. Diatom stratigraphy of the late Pleistocene (Brunhes) subarctic Pacific. Mar. Micropaleontol., 9: 263-274.

, 1986. Pliocene-Pleistocene evolution of the North Pacific oceanatmosphere system, interpreted from fossil diatoms. Paleoceanography, $1: 163-180$.

Schmidt, A., Schmidt, M., Fricke, F., Heiden, H., Müller, O., and Hustedt, F., 1874-1959. Atlas der Diatomeen-kunde: Leipzig (R. Reisland).

Schrader, H.-J., 1973. Cenozoic diatoms from the northeast Pacific, Leg 18. In Kulm, L. D., von Huene, R., et al., Init. Repts. DSDP, 18: Washington (U.S. Govt. Printing Office), 673-797.

1979. Opal phytoplankton in DSDP Leg 49 samples. In Luyendyk, B. P., Cann, J. R., et al., Init. Repts. DSDP 49: Washington (U.S. Govt. Printing Office), 589-593.

Schrader, H. J., and Fenner, J., 1976. Norwegian sea cenozoic diatom biostratigraphy and taxonomy. In Talwani, M., Udintsev, G., et al., Init. Repts. DSDP, 38: Washington (U.S. Govt. Printing Office), 921-1098.

Schumann, J., 1867. Die Diatomeen der Honen Tatra. Verh. Zool. Bot. Ges. Wien, 17:1-102.

Semina, G. I., 1956. De species nova generis Denticula Kütz notula. Nov. Syst. Plant. Non Vasc., Bot. Inst., Akad. Nauk. SSSR, 11:8284.

Shädbolt, G., 1854. A short description of some new forms of Diatomaceae from Port Natal. Trans. Microsc. Soc. London, n.s., 2:13-18.

Sheshukova-Poretzkaya, V. S., 1962. New and rare diatoms from formations of Sakhalin (in Russian). Uch. Zap. LGU, Ser. Biol. Nauk. (Lenigrad Univ.), 49:1-203.

1967. Neogene marine diatoms of Sakhalin and Kamchatka (in Russian). Izd. Leningrad Gos. Univ., 1-327. Simonsen, R., 1974. The diatom plankton of the Indian Ocean expedition of R/V Meteor 1964-1965. "Meteor" Forschungsergeb., ser. D, 19:1-107. 9-79.

Simonsen, R., and Kanaya, T., 1961. Note on the marine species of the diatom genus Denticula Kütz. Int. Rev. Gesamtan Hydrobiol., 46: 498-513.

Smith, W., 1856. Synopsis of the British Diatomaceae: London (John van Voorst).

Srivastava, S. P., Arthur, M. A., et al., 1987. Proc. ODP, Init. Repts., 105: College Station, TX (Ocean Drilling Program).

Tempère, J., and Peragallo, H., 1907-1915. Diatomées du Monde Entier. 2nd ed: Paris (Arcachon).

Thiede, J., Eldholm, 0., Taylor, E., et al., in press. Proc. ODP, Sci. Results., 104: College Station, TX (Ocean Drilling Program). 
Van Heurck, H., 1880-1885. Synopsis des diatomées de Belgique. Atlas: Antwerp (Ducaju and Cie.); text: Antwerp (Mtin. Brouwers \& Co.).

Wallich, G. C. 1860 . On the siliceous organisms found in the digestive cavities of the Salpae, and their relation to the flint nodules of the Chalk Formation. Trans. Microsc. Soc. London, 8:36-55.

Williams, K., 1986. Recent Arctic marine diatom assemblages from bottom sediments in Baffin Bay and Davis Strait. Mar. Micropaleontol., 10:327-342.
Wornardt, W. W., 1967. Miocene and Pliocene marine diatoms from California. Occ. Pap. Calif. Acad. Sci., 63:1-108.

Zabelina, M. M., 1934. Diatoms from the Tertiary deposits of the eastern coast of Kamchatka (in Russian). Tr. Neft. Geol. Razved. Inst., ser. A, 48:3-19.

Date of initial receipt: 21 July 1987

Date of acceptance: 5 February 1988

Ms 105B-127

diatoms

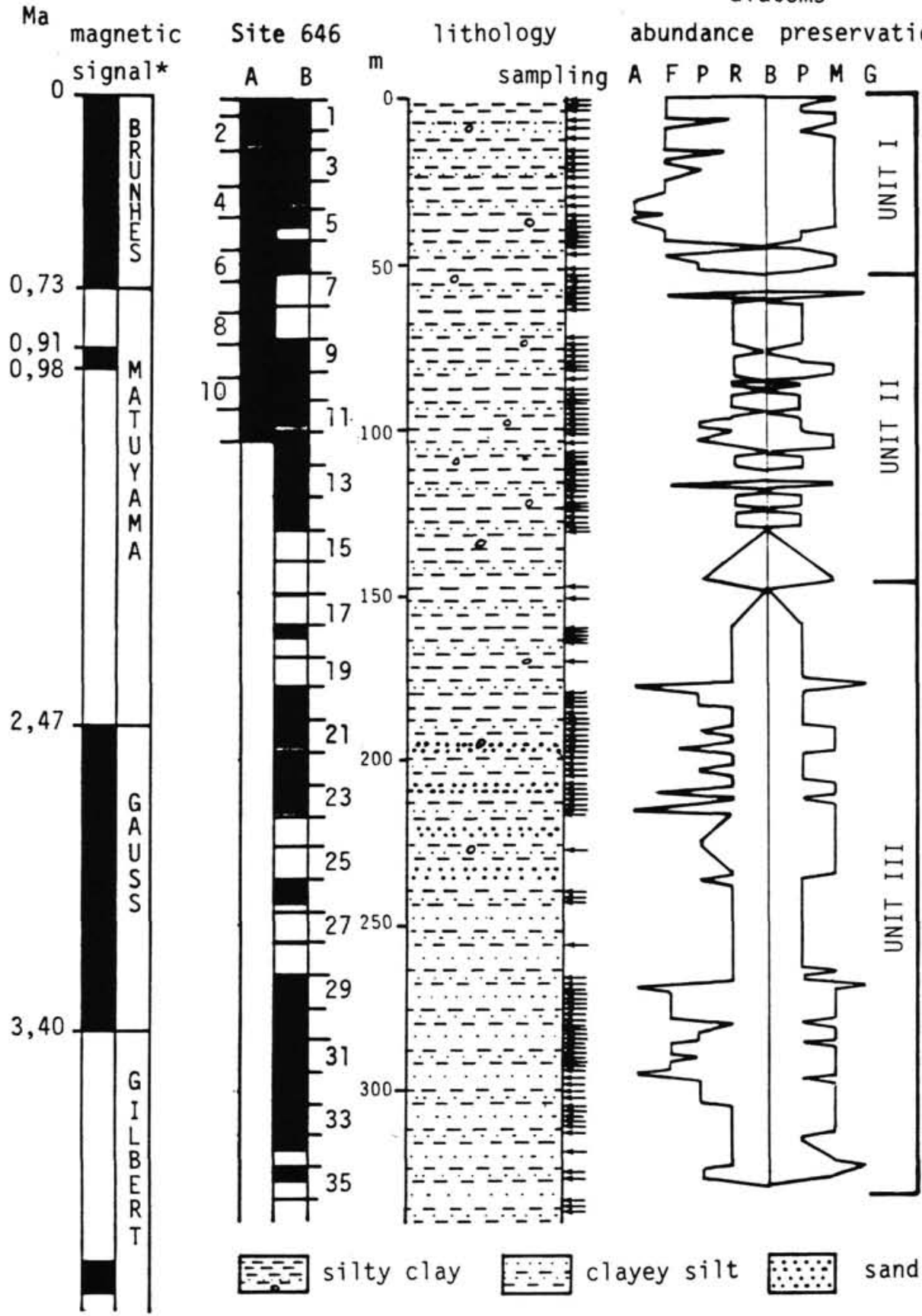

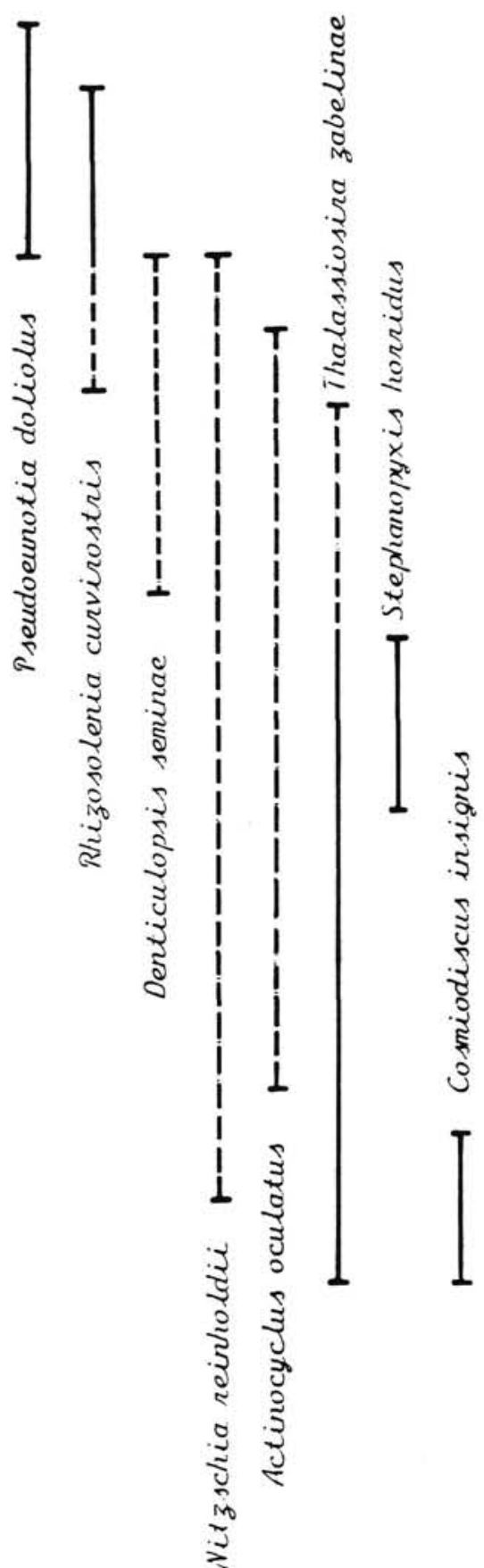

Figure 4. Stratigraphic ranges of selected diatoms from Hole $646 \mathrm{~A}$ and $646 \mathrm{~B}$ correlated with the paleomagnetic record completed for these holes $\left({ }^{*}=\right.$ Clement et al., this volume) and with the abundance $(\mathrm{A}=$ abundant, $\mathrm{C}=$ common, $\mathrm{F}=$ few, $\mathrm{R}=$ rare, and $\mathrm{B}=$ barren) and preservation $(\mathrm{G}=$ good, $\mathrm{M}=$ moderate, $\mathrm{P}=$ poor, and $\mathrm{B}=$ barren) of the diatom assemblages. 


\section{APPENDIX}

Floral List

Actinocyclus curvatulus Janisch, 1878 in Schmidt et al., 1874-1959, Pl. 57, Fig. 31; Hustedt, 1958, pp. 129-130, Pl. 8, Fig. 81; Baldauf, 1984, Pl. 1, Fig. 9, and Pl. 2, Fig. 8; Sancetta, 1982, pp. 222-224, Pl. 1, Figs. 1-3.

Actinocyclus ehrenbergii Ralfs in Pritchard, 1861, p. 834; Hustedt, 1929, p. 525, Fig. 298.

Actinocyclus ellipticus Grunow in Van Heurck, 1883, Pl. 124, Fig. 10; Akiba, 1985, Pl. 16, Fig. 5; Barron, 1985a, p. 779, Fig. 9.14; (Pl. 2, Fig. 3).

Actinocyclus oculatus Jousé, 1968, p. 18, Pl. 2, Figs. 6-7; Akiba and Yanagisawa, 1985, p. 494, Pl. 46, Figs. 13, 15-16; Barron, 1985a, p. 780, Fig. 9.1; (Pl. 2, Figs. 1-2).

Actinocyclus tenellus (Brébrisson) Andrews, 1976, p. 14, Pl. 3, Figs. 89; Andrews and Abbott, 1985, p. 68, Pl. 6, Figs. 2-3; synonyms: Eupodiscus tenellus Brébrisson, 1854, p. 257, Pl. 1, Fig. 9; Actinocyclus ehrenbergii var. tenella (Brébrisson) Hustedt, 1929, p. 530, Fig. 302; (Pl. 2, Fig. 5).

Actinoptychus senarius s. l. (Ehrenberg) Ehrenberg, 1841 (1843), p. 400, Pl. 1, Fig. 27; Hustedt, 1929, pp. 475-478, Fig. 264; Sancetta, 1982, p. 225, Pl. 1, Fig. 7; Andrews and Abbott, 1985, p. 70, Pl. 6, Figs. 14-15, and Pl. 12, Figs. 1-2; synonyms: Actinocyclus senarius Ehrenberg, 1838, p. 172, Pl. 21, Fig. 6; Actinoptychus undulatus (Bailey) Ralfs in Pritchard, 1861; (Pl. 2, Fig. 6)

Actinoptycus splendens (Shädbolt) Ralfs in Pritchard, 1861; Hustedt, 1929, p. 478, Fig. 265; Fenner, 1978, p. 510, Pl. 15, Fig. 1; synonyms: Actinosohaenia splendens Shädbolt 1854, p. 16.

Actinoptychus vulgaris Schumann, 1867, p. 64; Sheshukova-Poretzkaya, 1967, p. 187, Pl. 28, Figs. 2a-d; Sancetta, 1982, p. 225, Pl. 1, Fig. 8; Akiba, 1985, Pl. 29, Fig. 1.

Arachnodiscus spp.

Asteromphalus robustus Castracane, 1875 , p. 393, Pl. 6, Fig. 5; Hustedt, 1929, p. 496, Fig. 278; Baldauf, 1987, Pl. 3, Fig. 4; (Pl. 3, Fig. 14).

Azpeitia nodulifer (Schmidt) Fryxell and Sims in Fryxell, Sims, and Watkins, 1986, pp. 19-20, Figs. XVII, XVIII, XXX; synonym: Coscinodiscus nodulifer Schmidt in Schmidt et al., 1874-1959, Pl. 59, Figs. 20-23; Barron, 1985a, p. 781, Figs. 10.10-10.11; Barron, 1985b, Pl. 3, Fig. 1.

Azpeitia tabularis (Grunow) Fryxell and Sims in Fryxell, Sims, and Watkins, 1986, pp. 16-18, Figs. XIV, XV, XXX-1; synonym: Coscinodiscus tabularis Grunow, 1884, p. 86; Schmidt et al., 1878, Pl. 57, Fig. 43; Barron, 1985b, Pl. 3, Fig. 4; (Pl. 2, Fig. 4).

Bacteriastrum hyalinum Lauder, 1864, p. 8, Pl. 3, Fig. 7; Baldauf, 1984, Pl. 1, Fig. 5; Baldauf, 1987, Pl. 6, Fig. 10.

Bacterosira fragilis Gran, 1900, p. 114; Jousé, 1962, Figs. 2-15; Sancetta, 1982, p. 227, Pl. 2, Figs. 1-4; synonym: Coscinodiscus bathyomphalus Cleve, 1883, Pl. 38, Fig. 81.

Chaetoceros diadema (Ehrenberg) Gran, 1897, p. 20, Pl. 2, Figs. 16-18; synonym: Syndendrium diadema Ehrenberg, 1854, Pl. 35A/18, Fig. 13; (Pl. 2, Figs. 9-10).

Cocconeis spp.

Coscinodiscus asteromphalus Ehrenberg, 1844a, p. 77; Barron, 1975, p. 132, Pl. 6, Fig. 3; Abbott and Andrews, 1979, p. 235, Pl. 2, Fig. 8.

Coscinodiscus marginatus Ehrenberg, 1841, p. 142; Baldauf, 1987, $\mathrm{Pl}$. 1, Figs. 1, 8; Akiba, 1985, p. 442, Pl. 1, Figs. 1-4; (Pl. 2, Fig. 8).

Coscinodiscus oculus-iridis Ehrenberg, 1839, p. 147; Ehrenberg, 1854, Pl. 18, Fig. 42, and Pl. 19, Fig. 2; Sancetta, 1982, p. 229, Pl. 2, Fig. 11; Abbott and Andrews, 1979, p. 238, Pl. 3, Fig. 4.

Coscinodiscus radiatus Ehrenberg, 1839, p. 148, Pl. 3, Figs. 1a-c; Hustedt, 1930, p. 420, Fig. 225; Fenner, 1978, Pl. 7, Fig. 6.

Cosmiodiscus insignis Jousé 1959, Pl. 4, Fig. 9; Jousé, 1961, p. 67, Pl. 2, Fig. 8; Akiba, 1985, Pl. 17, Fig. 1; Barron, 1985a, p. 783, Fig. 9.9; (Pl. 2, Fig. 7, 9).

Denticulopsis hustedtii (Simonsen and Kanaya) Simonsen, 1979, p. 64; Akiba and Yanagisawa, 1985, p. 488, Pl. 17, Figs. 4-5, 7-23, Pl. 18, Figs. 1-10, and PI. 19, Figs. 1-5; Barron, 1985a, p. 784, Fig. 13.17; synonym: Denticula hustedtii Simonsen and Kanaya, 1961, p. 501, Pl. 1, Figs. 19-25; (P1. 3, Fig. 12).

Denticulopsis seminae (Simonsen and Kanaya) Simonsen, 1979, p. 65; Sancetta, 1982, pp. 230-231, Pl. 3, Figs. 1-3; synonyms: Denticula seminae Simonsen and Kanaya, 1961, p. 503, Pl. 1, Figs. 26-30;
Denticula marina Semina, 1956, p. 82, Figs. 1a-2b, nom invalide; Denticula seminae Simonsen and Kanaya, 1961, p. 503, Pl. 1, Figs. 26-30; (Pl. 3, Fig. 11).

Diploneis smithii (Brébrisson) Cleve, 1894, p. 96; Hustedt, 1837, p. 647, Fig. 1051; Akiba, 1985, Pl. 30, Fig. 8; synonym: Navicula smithi Brébrisson in Smith, 1856, p. 92.

Diploneis spp. Grammatophora spp.

Goniothecium decoratum Brun, 1891, p. 28, Pl. 12, Fig. 6; Schrader and Fenner, 1976, Pl. 6, Figs. 3, 5, and Pl. 37, Figs. 1-5, 11-14; Barron, 1985 a, p. 786 , Fig. 12.6 .

Hemidiscus cuneiformis Wallich, 1860, p. 42, Pl. 2, Figs. 3-4; Baldauf, 1984, Pl. 1, Figs. 6-7; Barron, 1985a, p. 786, Fig. 9.13.

Mediaria splendida Sheshukova-Poretzkaya, 1962, p. 210, Pl. 2, Fig. 5; Baldauf and Barron, 1982, Pl. 7, Fig. 15; Barron, 1985a, p. 786, Fig. 12.1.

Melosira sol (Ehrenberg) Kützing, 1849, p. 31; Sancetta, 1982, pp. 231232, Pl. 3, Figs. 4-5; synonym: Gallionella sol Ehrenberg, 1844b, p. 202.

Navicula sp. 3 .

Navicula spp.

Nitzschia cylindra (Grunow) Hasle, 1972, p. 115; Sancetta, 1982, p. 232, Pl. 3, Figs. 6-7; synonyms: Fragilaria cylindrus Grunow, 1884, p. 107, Pl. 2, Fig. 13; Hustedt, 1931, p. 152, Fig. 665; Fragilariopsis cylindrus (Grunow) Helmcke and Krieger, 1954, p. 17; Hustedt, 1958 , p. 162, Figs. 145-146.

Nitzschia fossilis (Frenguelli) Kanaya and Koizumi; Baldauf, 1984, Pl. 8, Figs. 8-9; Barron, 1985a, p. 787, Fig. 13.3; synonym: Pseudonitzschia fossilis Frenguelli, 1949, p. 118, Pl. 1, Figs. 6-7; (Pl. 3, Fig. 3).

Nitzschia grunowii Hasle, 1972, p; 115; Sancetta, 1982, p. 233, Pl. 3, Figs. 8-10; Akiba, 1985, Pl. 24, Figs. 19-21; synonyms: Fragilaria oceanica Cleve, 1873, p. 22, Pl. 4, Fig. 25; Hustedt, 1931, p. 148, Fig. 662; Fragilariopsis oceanica (Cleve) Hasle, 1965, Pl. 1, Figs. 15-19, Pl. 2, Figs. 6-9, Pl. 3, Figs. 1-2, and Pl. 16, Figs. 1-2; (Pl. 3, Fig. 2).

Nitzschia marina Grunow in Cleve and Grunow, 1880, p. 70; Baldauf, 1984, Pl. 5, Figs. 1-2; Barron, 1985a, p. 788, Fig. 13.1; (Pl. 3, Fig. 9).

Nitzschia reinholdii Kanaya emend. Barron and Baldauf, 1986, p. 364, Pl. 2, Fig. 7; synonyms: Fragilariopsis pliocena (Brun) SheshukovaPoretzkaya of Koizumi, 1968, Pl. 34, Figs. 13-15; Fragilaria pliocena Brun, 1891, p. 28, Pl. 14, Fig. 7; Nitzschia pliocena (Brun) Wornardt, 1967, p. 88, Figs. 212-213; (Pl. 3, Fig. 8).

Nitzschia spp.

Odontella aurita Agardh, 1832, p. 56; synonym: Diatoma auritium Lyngbye, 1819, p. 182, Pl. 62, Fig. D; Biddulphia aurita (Lyngbye) Brébrisson and de Godey, 1835, p. 12.

Opephora sp. 1 Baldauf, 1984, PI. 4, Fig. 9.

Paralia sulcata (Ehrenberg) Cleve, 1873, p. 7; Hendey, 1964, p. 73, Pl 23, Fig. 5; synonyms: Gaillonella sulcata Ehrenberg, 1838, p. 170 , Pl. 21, Fig. 5; Melosira sulcata (Ehrenberg) Kützing 1844, p. 55, P1. 2, Fig. 7.

Porosira glacialis (Grunow) Jòergensen, 1905, p. 97, Pl. 6, Fig. 7; Schrader and Fenner, 1976, p. 993, Pl. 16, Figs. 1-4, 13, and Pl. 17, Fig. 1; Sancetta, 1982, p. 235, Pl. 3, Figs. 16-18; synonym: Porosira hormeides var. glacialis Grunow, 1884, p. 108, Pl. 5e, Fig. 32.

Pseudoeunotia doliolus (Wallich) Grunow in Van Heurck, 1881, Pl. 35, Fig. 32; Akiba, 1985, Pl. 22, Figs. 1-2; Barron, 1985a, p. 788, Fig. 13.2; synonym: Synedra doliolus Wallich, 1860, p. 48, Pl. 2, Fig. 19; (Pl. 3, Fig. 4).

Pseudopyxilla americana (Ehrenberg) Forti, 1909, p. 14, Pl. 1, Figs. 67; Schrader, 1973, p. 708, Pl. 10, Fig. 22; synonym: Rhizosolenia americana Ehrenberg, 1841 (1843), p. 422.

Psuedopyxilla directa (Pantoscek) Forti, 1909, p. 13; Schrader and Fenner, 1976, Pl. 9, Figs. 8-9, and Pl. 44, Fig. 12; synonym: Pyxilla directa Pantoscek 1892, Pl. 32, Fig. 458.

Pterotheca spada Tempére and Brun in Brun and Tempére, 1889, p. 50, Pl. 1, Fig. 7; Schrader and Fenner, 1976, p. 994, Pl. 41, Figs. 4, 5, 12,13 .

Pyxilla spp.

Rhaphoneis amphiceros Ehrenberg, 1844a, p. 87; Hustedt, 1959, p. 174, Figs. 680-681; Schrader, 1973, pp. 708-709, Pl. 25, Figs. 2-3.

Rhaphoneis spp.

Rhizosplenia barboi (Brun) Tempére and Pergallo, 1908, p. 26; Akiba and Yanagisawa, 1986, p. 497, Pl. 42, Figs. 3-5, 7, 10-11, and Pl. 
44, Figs. 1-8; Barron, 1985a, p. 789, Fig. 12.5; synonyms: Pyxilla barboi Brun, 1894, p. 87, Pl. 5, Figs. 16-17, 23; Rhizosolenia curvirostris var. inermis Jousé, 1971, Pl. 15, Fig. 2; (Pl. 3, Fig. 5).

Rhizosolenia curvirostris Jousé, 1959, p. 48, Pl. 2, Fig. 17; Akiba and Yanagisawa, 1985, p. 497, Pl. 42, Figs. 1-2, and Pl. 45, Figs. 1-6; Barron, 1985a, p. 789, Fig. 12.4; (Pl. 3, Fig. 1).

Rhizosolenia hebetata Bailey, 1856, p. 5, Pl. 1, Figs. 18-19; Baldauf, 1987, Pl. 6, Fig. 3; (Pl. 3, Fig. 6-7).

Rhizosolenia styliformis Brightwell, 1858, p. 94, Pl. 5, Fig. 5; Baldauf, 1987, Pl. 6, Fig. 7; Akiba, 1985, Pl. 18, Fig. 4.

Rouxia spp.

Stellarima microtrias Hasle and Sims, 1986, p. 111, Figs. 18-27; synonyms: Coscinodiscus symbolophorus Grunow, 1884, p. 82, Pl. 4, Figs. 3-6; Baldauf and Barron, 1982, Pl. 4, Fig. 1; Akiba, 1985, Pl. 2, Fig. 1; Coscinodiscus stellaris (Roper) Heiden var. symbolophora (Grunow) Heiden in Heiden and Kolbe, 1927, p. 471; Symbolophora furcata (Karsten) Nikolaev 1983, p. 1124, Pl. 1, Figs. 8-9; (Pl. 4, Fig. 1).

Stellarima stellaris (Roper) Hasle and Sims, 1986, p. 111; synonyms: Coscinodiscus stellaris Roper, 1858, p. 21, Pl. 3, Fig. 3; Fryxell and Hasle, 1973, Pl. 8, Figs. 30-31; Symbolophora stellaris (Roper) Nikolaev, 1983, p. 1124, Pl. 2, Fig. 1-3.

Stephanogonia hanzawae Kanaya, 1959, p. 118, Pl. 11, Figs. 3-7; Schrader and Fenner, 1976, p. 1000, Pl. 12, Figs. 10, 12, and Pl. 13, Figs. 5, 7, 8; (Pl. 3, Fig. 13).

Stephanogonia sp. 1 (Pl. 4, Fig. 4)

Stephanopyxis dimorpha Schrader, 1973, p. 711, Pl. 15, Figs. 9-11, 1920, Pl. 16, Figs. 1-3, 8-11, and Pl. 24, Fig. 10; Akiba, 1985, Pl. 4, Fig. 13; Barron, 1980, Pl. 2, Figs. 13-14.

Stephanopyxis horridus Koizumi, 1972, p. 348, Pl. 42, Figs. 1-2; Barron, 1985a, p. 790, Fig. 12.13; Koizumi, 1973, Pl. 6, Figs. 1-4; (Pl. 3, Fig. 10).

Stephanopyxis turris (Greville and Arnott) Ralfs in Pritchard, 1861, p. 826, Pl. 5, Fig. 74; Hustedt, 1928, pp. 304-307, Fig. 140; Andrews and Abbott, 1985, p. 85, Pl. 9, Fig. 23; Fenner, 1978, p. 532, Pl. 12, Fig. 7; synonym: Creswellia turris Greville and Arnott in Gregory, 1857 , p. 538, Pl. 14, Fig. 109.

Stephanopyxis sp. 3.

Synedra tabulata (Agardh) Kützing, 1844, p. 68, Pl. 15, Fig. 10 (1-3); Hendey, 1964, p. 162; synonym: Diatoma tabulata Agardh, 1832, p. 50.

Thalassionema nitzschioides (Grunow) H. and M. Pergallo, 1901, p. 320; Sancetta, 1982, Pl. 4, Figs. 11-13; Akiba, 1985, Pl. 21, Fig. 11; synonyms: Synedra nitzschioides Grunow, 1862, p. 403, Pl. 5, Fig. 18; Thalassiothrix nitzschioides Grunow in Van Heurck, 1881, Pl. 43 , Figs. 7-10.

Thalassiosira antiqua (Grunow) Cleve-Euler, 1941, p. 173, Fig. 4; Barron, 1985a, p.791, Fig. 11.2; Akiba and Yanagisawa, 1985, p. 498, Pl. 51, Figs. 1-2, 4, and Pl. 52, Figs. 1-9; synonym: Coscinodiscus antiquus Grunow, 1884 , p. 84 , Pl. 4(D), Fig. 24

Thalassiosira decipiens (Grunow) Jòergensen, 1905, p. 96, Pl. 6, Fig. 3; Sancetta, 1982, pp. 241-242, Pl. 5, Figs. 1-3; synonyms: Coscinodiscus excentricus var.? decipiens Grunow, 1878, p. 125 (28), Pl. 4, Fig. 18; Coscinodiscus decipiens Grunow in Van Heurck, 1882, Pl. 91, Fig. 10.

Thalassiosira eccentrica (Ehrenberg) Cleve 1903-1904, p. 216; Hustedt, 1928, p. 338, Figs. 201a-b; Fryxell and Hasle, 1972, p. 300, Pl. 1, Figs. 1a-2, Pl. 2, Figs. 3-10, Pl. 3, Figs. 11-15, and Pl. 4, Figs. 16-
18; Simonsen, 1974, p. 9, Pl. 2, Figs. 1-3; synonym: Coscinodiscus eccentricus Ehrenberg, 1839, p. 146.

Thalassiosira gravida Cleve, 1896, p. 12, Pl. 2, Figs. 14-16; Hustedt, 1928 , p. 325, Fig. 161; Akiba, 1985, Pl. 10, Fig. 1-4; Koizumi, 1973, Pl. 7, Fig. 19-21.

Thalassiosira grunowii Akiba and Yanagisawa, 1985, p. 493, Pl. 27, Fig. 5, Pl. 29, Figs, 1-8b, and Pl. 30, Figs. 1-10; synonym: Coscinodiscus plicatus Grunow in Schmidt et al., 1878, Pl. 59, Fig. 1; Barron, 1985a, p. 782, Figs. 10.1-10.2; Barron, 1985b, Pl. 7, Fig. 10; (Pl. 1, Fig. 1).

Thalassiosira hyalina (Grunow) Gran, 1897, p. 4, Pl. 1, Figs. 17-18; Hustedt, 1928, p. 323, Fig. 159; Sancetta, 1982, p. 242, Pl. 5, Figs. 4-5; Akiba, 1985, Pl. 5, Fig. 9; synonym: Coscinodiscus hyalinus Grunow in Cleve and Grunow, 1880, p. 113, Pl. 7, Fig. 128.

Thalassiosira jacksonii Koizumi and Barron in Koizumi, 1980, p. 396, Pl. 1, Figs. 11-14; Barron, 1980, Pl. 6, Figs. 2, 6; Akiba, 1985, Pl. 11, Fig. 2.

Thalassiosira lacustris (Grunow) Hasle in Hasle and Fryxell, 1977; Sancetta, 1982, p. 243, Pl. 5, Figs. 6-7; synonym: Coscinodiscus lacustris Grunow in Cleve and Grunow, 1880, p. 114.

Thalassiosira leptopus (Grunow) Hasle and Fryxell, 1977, pp. 20-22, Pls. 1-4 and Pl. 18, Figs. 94-96; Akiba, 1985, Pl. 14, Fig. 12; Andrews and Abbott, 1985, p. 86, Pl. 9, Figs. 29-30; synonyms: Coscinodiscus lineatus var. leptopus Grunow in Van Heurck, 1883, PI 131, Figs. 5-6; Coscinodiscus leptopus Grunow in Rattray, 1889, p. 476; Coscinodiscus lineatus Ehrenberg, 1838, p. 129; Ehrenberg, 1854, Pl. 18, Fig. 33.

Thalassiosira nidulus (Tempére and Brun) Jousé, 1961, p. 3, Pl. 1, Figs. 3-4; Koizumi, 1973, Pl. 7, Fig. 25, not Fig. 6; Akiba, 1985, Pl. 6, Figs. 5-7; synonym: Stephanopyxis nidulus Tempére and Brun in Brun and Tempére, 1889, p. 57, Pl. 8, Fig. 10; (Pl. 1, Fig. 7).

Thalassiosira nordenskioeldii Cleve, 1873, p. 7, Pl. 1, Fig. 11; Hustedt, 1928, p. 321, Fig. 157; Sancetta, 1982, p. 242, Pl. 5, Figs. 8-9; Akiba, 1985, p. 446, Pl. 5, Fig. 8; (Pl. 1, Fig. 5).

Thalassiosira oestrupii (Ostenfeld) Proschkina-Lavrenko ex Hasle, 1960 p. 8, Pl. 1, Figs. 5-7, 11; Akiba, 1985, Pl. 14, Figs. 1-6; Barron, 1985a, p. 792, Figs. 11.5-11.6; synonym: Coscinosira oestrupii Ostenfeld, 1900, p. 52; (Pl. 1, Figs. 8-9).

Thalassiosira trifulta Fryxell in Fryxell and Hasle, 1979, p. 16, Pl. 1-5, Figs. 1-24; Sancetta, 1982, p. 244, Pl. 5, Figs. 10-12; Akiba, 1985, Pl. 10, Figs. 5-7; synonyms: Coscinodiscus excentricus Ehrenberg Koizumi, 1973, Pl. 2, Figs. 11-12; Coscinodiscus excentricus var. jousei Kanaya, Koizumi, 1973, p. 832, Pl. 3, Figs. 1-6; Coscinodiscus excentricus var. leasareolatus Kanaya, Koizumi, 1973, p. 832, Pl. 3, Figs. 7-11; (Pl. 1, Figs. 2, 6).

Thalassiosira usatchevii Jousé, 1959, p. 55, Pl. 4, Figs. 14-15; Jousé, 1961, p. 64, Pl. 1, Fig. 10; (Pl. 4, Fig. 2).

Thalassiosira zabelinae Jousé, 1959, p. 41, Pl. 2, Figs. 1a-1b; Akiba, 1985, Pl. 8, Fig. 11; Barron, 1985a, p. 793, Fig. 11.10; (Pl. 4, Fig. 3).

Thalassiosira yabei (Kanaya) Akiba and Yanagisawa, 1985, Pl. 27, Figs. 1-2, and Pl. 28, Figs. 1-9; synonym: Coscinodiscus yabei Kanaya, 1959 , p. 86, Pl. 5, Figs. 6-9; (Pl. 1, Fig. 3).

Thalassiosira spp. 3.

Thalassiosira spp. "plicate group". Plicate species closely related to Thalassiosira lacustris (Grunow) Hasle.

Thalassiothrix longissima Cleve and Grunow, 1880, p. 108; Akiba, 1985, Pl. 21, Fig. 18; Baldauf and Barron, 1982, Pl. 7, Figs. 11-12.

Trinacria spp. 


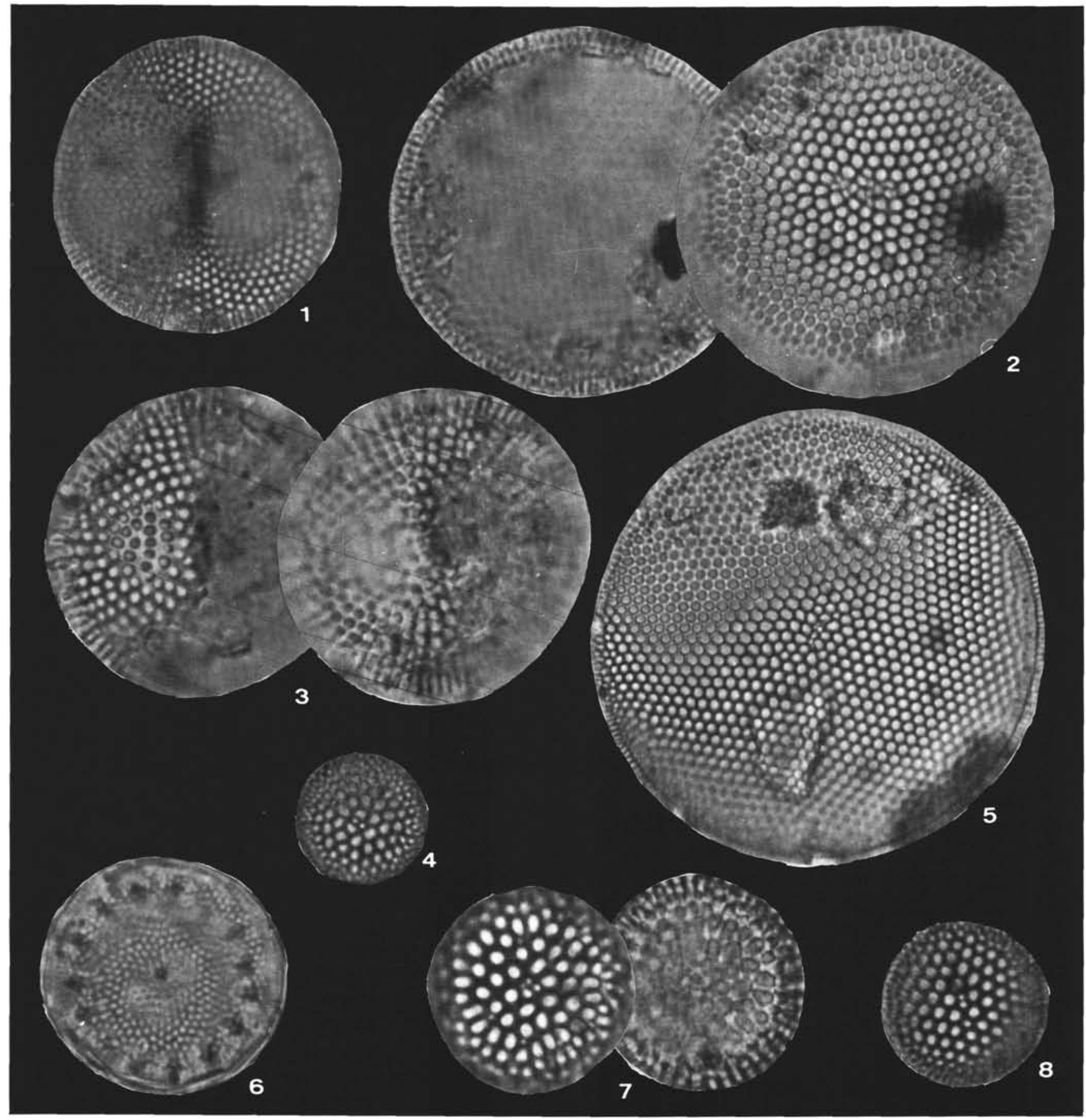

Plate 1. 1. Thalassiosira grunowii Akiba and Yanagisawa, Sample 105-646B-35X-1, 124-126 cm, diameter $=48.5 \mu \mathrm{m}(\times 1000)$. 2, 5. Thalassiosira trifulta Fryxell, (2) Sample 105-646A-5H, CC, diameter $=32 \mu \mathrm{m}(\times 2000)$; (5) Sample 105-646A-7H-5, 120-122 cm, diameter $=51 \mu \mathrm{m}$ $(\times 1500)$. 3. Thalassiosira yabei (Kanaya) Akiba and Yanagisawa, Sample 105-646B-29X-2,115-117 cm, diameter $=25 \mu \mathrm{m}(\times 2000)$. 4, 8. Thalassiosira oestrupii (Ostenfeld) Proshkina-Lavrenko, (4) Sample 105-646B-11H-2, 124-126 cm, diameter $=13 \mu \mathrm{m}(\times 2000)$; (8) Sample 105-646A-7 H-2, $120-122 \mathrm{~cm}$, diameter $=10 \mu \mathrm{m}(\times 2000)$. 6. Thalassiosira nordenskioeldii Cleve, Sample 105-646B-29X-5, $115-118 \mathrm{~cm}$, diameter $=20 \mu \mathrm{m}$ $(\times 2000)$. 7. Thalassiosira sp., Sample 105-646B-35X-1, 124-126 cm, diameter $=16 \mu \mathrm{m}(\times 2000)$. 


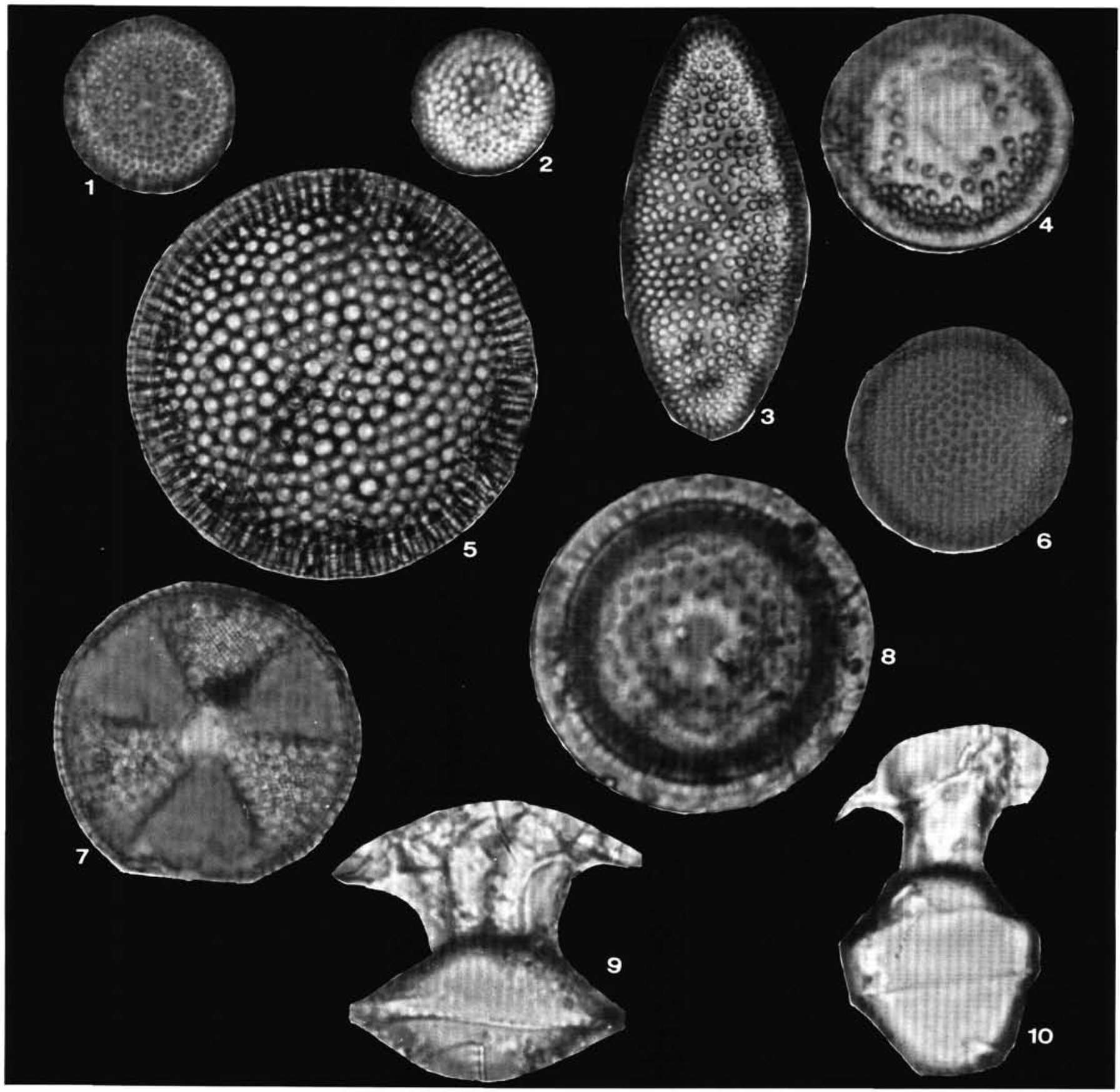

Plate 2. 1-2. Actinocyclus oculatus Jousé,(1) Sample 105-646A-5H-1, 120-122 cm, diameter $=15 \mu \mathrm{m}(\times 2000)$; (2) Sample $105-646 \mathrm{~A}-5 \mathrm{H}-1,120-$ $122 \mathrm{~cm}$, diameter $=11 \mu \mathrm{m}(\times 2000)$. 3. Actinocyclus ellipticus Grunow, Sample 105-646B-29X-2, 115-116 cm, length $=36 \mu \mathrm{m}(\times 2000) .4$, 8. Cosmiodiscus insignis Jousé, (4) Sample 105-646B-31X-4, 123-125 cm, diameter $=27 \mu \mathrm{m}(\times 1500)$; $(8)$ Sample $105-646 \mathrm{~B}-31 \mathrm{X}-4,123-125 \mathrm{~cm}$, diameter $=28 \mu \mathrm{m}(\times 2000)$. 5. Coscinodiscus marginatus Ehrenberg, Sample 105-646A-5H-1, 120-122 cm, diameter $=94 \mu \mathrm{m}(\times 750) . \quad 6$. Actinocyclus tenellus (Brébrisson) Andrews, Sample 105-646B-29X-4, 115-117 cm, diameter $=35 \mu \mathrm{m}(\times 1500)$. 7. Actinoptychus senarius (Ehrenberg) Ehrenberg, Sample 105-646B-35X-1, 124-126 cm, diameter $=51 \mu \mathrm{m}(\times 1000)$. 9-10. Chaetoceros diadema (Ehrenberg) Gran, (9) Sample 105-646A-3H$4,128-130 \mathrm{~cm}$, diameter $=22 \mu \mathrm{m}(\times 2000)$; (10) Sample 105-646A-5H-3, 120-122 cm, diameter $=16 \mu \mathrm{m}(\times 2000)$. 


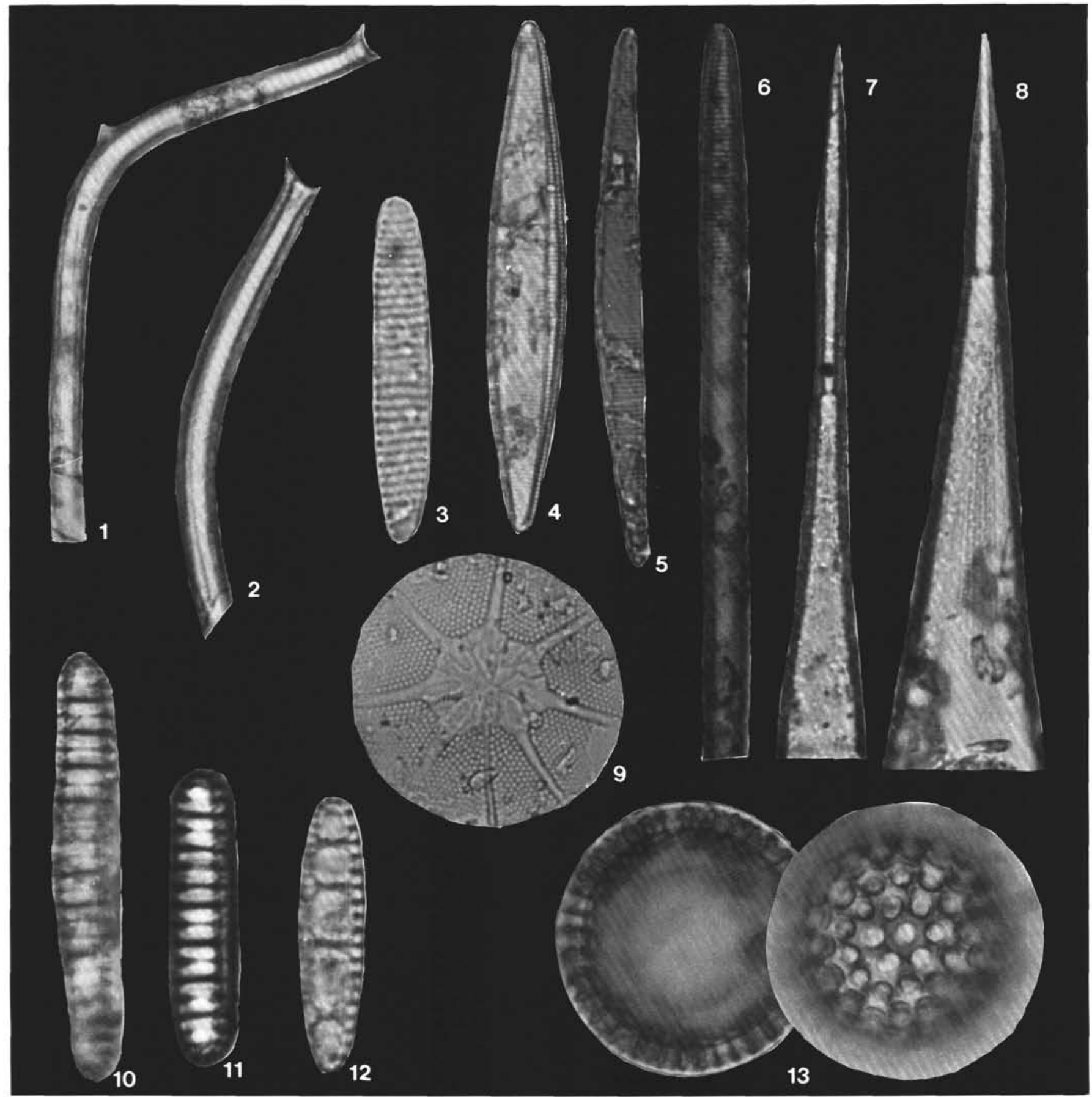

Plate 3. 1. Rhizosolenia curvirostris Jousé, Sample 105-646A-3H-2, $128-130 \mathrm{~cm}$, length $=120 \mu \mathrm{m}(\times 1000)$. 2. Rhizosolenia barboi (Brun) Tempére and Pergallo, Sample 105-646B-29X-4, 115-118 cm, length $=82 \mu \mathrm{m}(\times 1000)$. 3. Nitzschia grunowii Hasle, Sample 105-646A-5H-2, 120-122 $\mathrm{cm}$, length $=28 \mu \mathrm{m}(\times 2000)$. 4. Nitzschia reinholdii Kanaya ex Barron and Baldauf, Sample 105-646A-7H-5, $120-122 \mathrm{~cm}$, length $=86 \mu \mathrm{m}$ $(\times 1000)$. 5. Pseudoeunotia doliolus (Wallich) Grunow, Sample $105-646 \mathrm{~A}-5 \mathrm{H}-1,120-122 \mathrm{~cm}$, length $=91 \mu \mathrm{m}(\times 1000)$. 6. Nitzschia marina Grunow, Sample 105-646A-7H-5, 120-122 cm, length $=126 \mu \mathrm{m}(\times 1000) . \quad 7-8$. Rhizosolenia hebetata Bailey, (7) Sample 105-646A-5H-2, 120-122 cm, length $=132 \mu \mathrm{m}(\times 1000)$. (8) Sample 105-646B-13H-4, 114-116 cm, length $=120 \mu \mathrm{m}(\times 1000)$. 9. Asteromphalus robustus Castracane, Sample 105-646A-7H-5, 120-122 cm, diameter $=41 \mu \mathrm{m}(\times 1000)$. 10-11. Denticulopsis hustedtii (Simonsen and Kanaya) Simonsen, (10) Sample 105-646B$35 \mathrm{X}-1,124-126 \mathrm{~cm}$, length $=24 \mu \mathrm{m}(\times 2000)$; (11) Sample 105-646B-35X-1, 124-126 cm; length $=37 \mu \mathrm{m}(\times 2000)$. 12. Denticulopsis seminae $($ Simonsen and Kanaya) Simonsen, Sample 105-646A-9H-5, 98-100 cm, length $=23 \mu \mathrm{m}(\times 2000)$. 13. Stephanopyxis horridus Koizumi, Sample 105646B-21X-4, 130-132 cm, diameter $=46 \mu \mathrm{m}(\times 1000)$. 


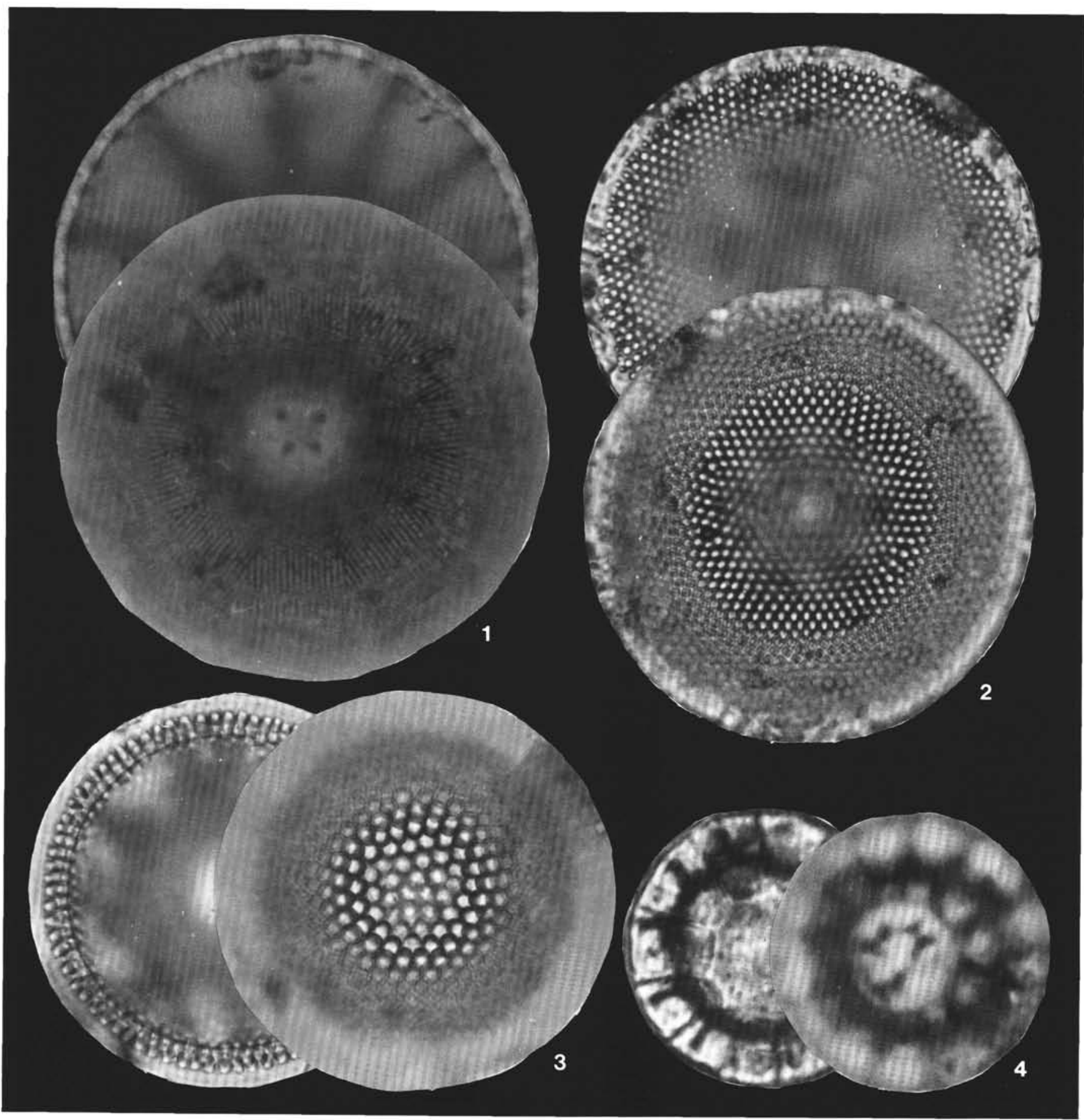

Plate 4. 1. Stellarima microtrias Hasle and Sims, Sample 105-646B-21X-4, 130-132 cm, diameter $=81.5 \mu \mathrm{m}(\times 1000)$. 2. Thalassiosira usatchevii Jousé, Sample 105-646B-23X-2, 126-128 cm, diameter $=78 \mu \mathrm{m}(\times 1000)$. 3. Thalassiosira zabelinae Jousé, Sample 105-646B-11H-6, 124-126 cm, diameter $=45 \mu \mathrm{m}(\times 1500)$. 4. Stephanogonia sp. 1, Sample 105-646B-23X-2, 126-128 cm, diameter $=43 \mu \mathrm{m}(\times 1000)$ 